\title{
The Rise and Fall of NWICO
}

\author{
From a Vision of International Regulation to a Reality of \\ Multilevel Governance
}

\author{
Ulla CARLsson
}

Global flows of news and information were the subject of intense debate in international fora in the 1970s. News gathering and reporting has been controversial, both within nations and between nations, as long as mass media have existed, but never - neither before nor since - have information flows been debated with such passion as in the 1970s. The United Nations, and UNESCO in particular, were the prime arenas where these issues were thrashed out.

In the decades immediately following the second world war, the media debate was mainly a protracted trench battle in the Cold War, where the West rallied around the principle of "free flow of information" and the Eastern bloc iterated the need for state control. Although this East-West dispute was by no means resolved in the 1960 s, the situation changed with the addition of a North-South dimension in the 1970s. Besides the opening of a new front, the focus of the dispute was broadened to include flows of other media products besides news, flows which were assuming increasing importance in international relations. A new perspective on the principle of "free flow of information" came to light.

These developments had their roots in the dramatic changes in world politics that took place in the 1960s. Numerous colonies gained independence from the colonial metropoles. With independence came demands for recognition of the countries' national sovereignty, not only in political terms, but economically and culturally, as well. The undertones in these demands often harmonized with those of the Eastern bloc. At the same time, the newly liberated countries were in dire need of development assistance from the

NORDICOM, Göteborg University, Box 713, SE 40530 Göteborg, ulla.carlsson@nordicom.gu.se industrialized countries. "Development", the process of evolution toward a modern society, occupied center stage. Scholars and development experts assigned mass communications a central role in the development process.

In the Cold War era the newly independent countries of the third world were of strategic importance to both East and West. Development aid was an important factor for "winning the hearts and minds" of developing countries. New patron-client relationships emerged; old, established ones evolved. The successes achieved by the oil-producing countries in OPEC in the 1970s strengthened the position of the third world as a bargaining partner (albeit rising fuel prices had serious impacts on some developing countries). In succeeding years, the third world made its voice heard in international fora as never before, formulating programs for farreaching reform. A set of demands that would result in a New International Economic Order was put on the agenda; demands for reform of existing patterns of news and information flows - in short: a new international infomation order - were soon to follow. But a new international information order, in the sense its authors intended, was not to be. After some brief years of debate, the issue disappeared from international agendas.

\section{The Purpose and Frame of Reference of the Study}

This article summarizes the findings of an analysis of the rise and fall of the political move to bring about a new world information and communication order. Now and again, the retrospective analysis casts light on features of the present 'world information order'. 
The study applies a holistic approach and tests alternative explanatory models in its exploration of the factors that precipitated the demand for a NWICO in the 1970s and the events and circumstances that led to the issue's subsidence and subsequent removal from international agendas. More general theories of development that recognize the role of media and mass communication in processes of socio-economic development and cultural and economic globalization guided the examination of how emerging media relate to communication systems and policy objectives. ${ }^{1}$

The framework of the study is inspired by the work of Anthony Giddens, particularly his work on a social theory, and modernity. Giddens sees the social structure as a dynamic entity that structures social action while at the same time being constituted through social action. As a consequence of this view, no relationship between the media and society can be presumed a priori; rather, the relationship has to be explored in its historical context. Contextual factors are all-important (Giddens 1984; Hjarvard 2001). In Giddens' view, the process of globalization follows from modernity; modernity is inherently globalizing. Four dimensions of modernity which tend toward globalization are identified: 1. the development of world markets; 2 . the rise of the nation-state system; 3 . the emergence of military blocs; and 4. industrialization. Giddens emphasizes the influence of communications technology as a factor in globalization and points out the key role media culture plays (Giddens 1990).

The issue of a NWICO is intimately bound up with global cold war politics. Three worlds were distinguished, the 'first' and 'second' of which advanced competing blueprints for how social life should be organized in order to achieve 'the good society'. The 'third' world emerged with the liberation of former colonies. These countries were 'underdeveloped' and would now, with the help of either the capitalist or the socialist world, be 'developed' into modern societies. This is not to say that the first and second worlds were equals, however. The interaction of the four dimensions of modernity mentioned above gave the West economic, political and military power which, at the time of the demands for a NWICO, could be described as hegemonic (cf. Giddens 1996:49-55). A belief that the world could be governed prevailed, and faith in international organizations like the United Nations and UNESCO were yet unshaken. It was in this point in time and space that the demands for a new international information order were raised.

\section{The Study}

In the following, the analysis of the rise and fall of NWICO as an issue will be presented in six parts. First, we shall consider the context surrounding the NWICO issue. The seeds from which the demand for a NWICO arose are to be found in the thinking about development that prevailed at the time of national independence and the forum for debate that UNESCO itself represented. Here we shall consider the factors that contributed to the rise of the issue, drawing on the findings of a separate study of the feasibility of regulating the media and communications sectors on an international level.

The next three segments consider the concept of a new international information order, its meaning, reactions to it, and the outcome and legacy of the debate. Here, too, a number of extensive studies have been undertaken. The contents and implications of NWICO are characterized on the basis of a systematic analysis of the documents from meetings of the the non-aligned countries. Then we follow the progress of the issue on the international agenda with particular attention to the final report of the MacBride Commission, as an expression of an attempt to solve an international problem. One study analyzed the ideas expressed in the proposals of the Commission from a variety of standpoints. Thereafter, we consider the findings of an analysis of the debate about the Commission report in UNESCO and the resolution that resulted from it. In the sixth segment, we look for the reasons why the demands failed; this part of the paper is based on an analysis of the minutes of UNESCO General Conferences after 1980.

By way of conclusion, features of the present world information order are described against the background of the NWICO issue with respect to its bearing on the globalization process, on media developments in third world countries and, ultimately, on current thinking about development and the governance of the media system.

\section{The Role of Mass Media in the Development Process}

\section{Two Paradigms of Development}

The issue of a new international information order is bound up with ideas about the role of communication in the development of societies, on the one hand, and the relations between developed and developing countries, on the other. The purpose of development is to improve the living conditions of the 
members of a society. Development is at once a process and a goal. What is needed to bring about development, and what constitutes "better living conditions" have been bones of contention ever since the days surrounding national independence from the colonial powers, starting in the late 1950s, and continuing into the 1970s.

National development arose as an issue in the wake of the second world war, and the issue made its entry onto the international agenda in the 1950s. It was introduced by the USA, now a world power and interested in exporting its model of society. The Marshall Plan (economic and technical assistance for the reconstruction of Europe), and the Truman Doctrine (mutual defense against aggression by third parties) played key roles in this regard. In addition, there was the founding of the United Nations and its specialized agencies, among them UNESCO, the United Nations Economic, Social and Cultural Organisation.

Initially, 'development' was mainly a question of economic growth, i.e., a steady and lasting increase in productivity and per capita income. There was an unshaken faith in technology and 'knowhow'. Two different schools of thought developed. The more dominant of the two envisioned "the passing of traditional society" (Lerner 1958), in favor of a modern, Western-style nation-state. Gradually, 'development' came to include political, social and cultural spheres, as well. The other school took its starting point in the model of socialist societies in Eastern Europe, China and Cuba and aimed, with assistance from the Soviet Union, to create nation-states with planned economies. Here, the motor force was not the market, but political decision-making.

These models of development coincided with the emergence of nationalist movements in many colonies in Asia and Africa. Modernism was part of the legacy of the colonial metropole, and the idea of a nation-state met strong and widespread resistance. At independence, however, European models of the nation-state prevailed. The new countries were in great need of assistance to combat poverty, illiteracy and unemployment. Concepts of development were therefore paramount in politics and the economic sphere.

Thus, the world of the 1960s was polarized along two dimensions: capitalism vs communism, and developed vs underdeveloped. These two dichotomies produce four worlds (Worsley 1984), but the third and fourth of these worlds, i.e., the underdeveloped countries adhering to capitalist and communist/socialist ideologies, respectively, melded and came to be referred to as the 'third world'. Their shared history and social and economic situation were more dominant than any differences that may have arisen after independence. The countries of the third world were all characterized by low degrees of industrialization, low per capita income, high rates of infant mortality, poor standard of public health, illiteracy, and extreme inequality. (Reeves 1993)

The development process became a prime focus in the contest to win the third world countries over. The role of mass media also assumed prominence in this process, not least due to technological advances. Scholars who have studied development in the postwar period up to the 1970s have identified phenomena and precepts that form two separate paradigms of development:

- The modernization paradigm: theories relating to modernization, political and economic development and technology transfer (Lerner 1958; McClelland 1961; Rogers 1962; Schramm 1964), and

- The dependence paradigm: theories relating to imperialism and underdevelopment and revolution and liberation (Baran 1957; Dos Santos 1970; Frank 1969; Galtung 1971).

Where the modernization school saw the problems of developing countries as the result of characteristics inherent in the history of the territories, the dependence paradigm pointed to underdevelopment as the result of capitalism and its expressions, colonialism and imperialism.

\section{Ideology and Strategy}

The concepts of 'development' and 'communication' are both partly normative; they stand for desirable forms of social change. As a consequence the modernization and dependence paradigms are normative. In the modernization paradigm, communication is seen to facilitate or hasten progress toward a modern, as opposed to traditional, society. In the dependence paradigm, it is rather a question of media imperialism. The modernization paradigm is essentially optimistic, whereas the dependence paradigm is essentially pessimistic about development in the countries of the third world.

But the two paradigms also express ideological standpoints, if by ideology we mean a system of ideas, political-economic, about the nature of the world, what it should be, and how best to go about achieving the goal. Ideology consists, in other words, of the following components: 
Figure 1. Features of the Modernization and Dependency Paradigms
Modernization
1. Western societies as a model - emphasis on economic growth
2. Causes of underdevelopment inherent in the countries themselves
3. Focus on the nation-state
4. Emphasis on individual freedoms
5. Mass media accorded a central role in the development process
6. Vertical pattern of communication - from the elite to the people.

\section{Dependence}

1. World systems perspective - development defined in terms of center and periphery

2. Underdevelopment ascribed to the industrialized capitalist powers of the West

3. Information gaps - underdevelopment in the periphery is prerequisite to development in the center

4. The mass media reinforce the dominance of the metropole over its satellites

5. A country in the periphery must strive for self-reliance and liberation from the world system

6. Emphasis on social equality.

\begin{abstract}
An ideology is a belief system by virtue of being designed to serve on a relatively permanent basis a group of people to justify in reliance on moral norms and a modicum of factual evidence and self-consciously rational coherence the legitimacy of the implements and technical prescriptions which are to ensure concerted action for the preservation, reform, destruction or reconstruction of a given order. (Seliger 1976, s 120).
\end{abstract}

The Cold War polarized ideological debates into two camps, a classical Liberal and a Marxist. The polarization is reflected in the two paradigms of development. Liberal features of the modernization paradigm are, for example, the norm of individual freedom and a preference for social change by consensus. The focus rests on the nation-state, and on internal dynamics in the development process. The dependence paradigm, on the other hand, is well aligned with Marxist theory, tending philosophically toward materialism and emphasizing social equality as a norm. Its approach to society is essentially conflict-oriented, and analyses focus on world capitalism as a system and on center-periphery dynamics in the development process. (cf. Tehranian 1994:282f)

The modernization paradigm was dominant in the 1950s and 1960s, and the views that characterize that paradigm largely coincide with the approach to development, with a decided emphasis on development assistance, that was embraced by the UN and UNESCO at that time. But when exponents of the dependence paradigm, who were critical of the modernization approach, demanded a change in policy in the 1960s, it marked the start of a 'war of ideas' in the international arena. In fora like the UN and UNESCO, each national representative had access to the floor and could air his views. It was here that the non-aligned states formed an alliance to demand a new international information order.

Thus, it was these two competing paradigms of development and their ideological components that constituted the fundaments for the ideas expressed in the debate on a new international information and communication that took place on the international plane, namely, in UNESCO.

\section{UNESCO: \\ International Arena for Issues Relating to Information and Communication}

\section{Background}

The concept of "free flow of information" was formulated in the USA in the final throes of the second world war. No national frontiers should be allowed to hinder the flow of information between countries. Before the war, Europe and the USA had shared control over the international news market. The USA was, however, excluded from the extensive territories under the control of colonial powers Great Britain and France, who controlled the flows of information in their colonies.

Even while the war was still raging, it was apparent that the USA would emerge from it as a world power. The U.S. saw before them a world without colonial ties, a world that lay open for an expansive economy in the U.S. The information sector was a key factor in paving the way for economic expansion. People everywhere were tired of the propaganda and censorship that were part of the 
war effort and welcomed the thought of 'free flows' warmly. The idea of a 'free flow of information' was spread over the world.

Newspaper publishers in the U.S. and representatives of the news agencies Associated Press (AP) and United Press (UP) traveled around the world, preaching the gospel of 'free flow'. It was particularly important to win support for the concept in the United Nations and especially its specialized agency, UNESCO. Thus, UNESCO came to be the main arena in which information and communication issues were debated in the postwar period.

In the following we shall particularly consider UNESCO's norm-setting function. Different approaches to formulating the principles of a NWICO are identified on the basis of a study of pertinent international law. The results of this study in turn form the starting point for an analysis of the totality of international agreements in the field of information and communication that relate to the juridical status of information and communication as objects of regulation.

\section{Three Roles}

UNESCO is often associated with development assistance, and in its first years the organization was indeed primarily an aid organ. There was a great need for reconstruction within UNESCO's sphere of activity after the war, and UNESCO did what it could to muster expertise and funding for the reconstruction effort. The emphasis on material assistance was reinforced when colonies began to free themselves from colonial metropoles and became nations in their own right. UNESCO, like the UN as a whole, came to be regarded as a system for the transfer of resources from rich countries to poor countries.

The assistance UNESCO provided in the $1950 \mathrm{~s}$ and 1960s was guided to a large extent by the faith American researchers had in the positive role mass media played in the development process, not least in promoting literacy. (Lerner 1958; Rogers 1962; Schramm 1964) UNESCO assistance mainly focused on technology transfer, both hardware (e.g., printing presses and broadcasting transmitters) and software (radio and TV programs). It was UNESCO's goal to ensure that every country had at least 10 copies of a daily newspaper, 5 radio receivers, 2 television sets and 2 cinema seats per thousand inhabitants.

A second major role for UNESCO was fact-finding. UNESCO collaborates with numerous organizations and arranges meetings and conferences on a variety of subjects. These result in books and reports. UNESCO is one of the largest publishing houses in the world. Innumerable reports the field of mass communications have been issued, with a marked peak in the late 1970s and early 1980s. The volumes report research findings, current thinking and opinion pieces, conference proceedings, and statistical compendia. This role doubtless contributed to UNESCO's becoming the principal arena of debate concerning systems of information and communication between nations and regions of the world.

Finally, UNESCO also has a norm-setting function that is founded in international law. Like many other bodies within the United Nations organization, UNESCO drafts and adopts international agreements between member nations. Whereas neither UNESCO nor any other UN body is invested with legislative powers, they have been instrumental in bringing about numerous international agreements. Today, the UN institutions have acquired such stature that they tend more and more to be considered legal entities. (Eek 1979; Eek et al.1987; Gross 1979) The UN Charter contains clauses that require member nations to observe the Charter's legal force and to adapt national legislation accordingly (Article 104). Thus, procedures for building up a body of law have been elaborated within the UN system. A certain interplay between the UN General Assembly and, for example, the UNESCO General Conference may be observed. Issues are discussed within UNESCO and are then forwarded to the mother organization and the General Assembly. Flows in the opposite direction also occur.

Some documents in international law have binding force for the signatories, and each must adopt and ratify the agreement individually. Most such documents are either treaties or conventions. UNESCO and similar institutions are highly instrumental in bringing such documents into the world. The Charters of the United Nations and UNESCO are, for that matter, examples of such treaties.

Declarations and resolutions lack the binding force of a treaty. Nonetheless, they are of juridical significance, playing a major role in the development of international law in, for example, the preliminary work on treaties and conventions. Declarations have higher rank than resolutions, and declarations and resolutions adopted by the UN General Assembly rank higher than declarations and resolutions adopted by specialized agencies like UNESCO. (Eek 1979) The term 'declaration' applies to documents, the purpose of which is to establish legal principles; in 
formal respects a declaration is similar to a convention. A resolution sets out policy for the organization that adopts it. A resolution may subsequently evolve into a document of international law. Researchers are agreed, however, that both resolutions and declarations adopted by the UN General Assembly must be taken into account when determining whether a given principle of international relations is to be considered part of the body of international law (Eek et al. 1987).

From the start, both the UN and UNESCO have had an explicit commitment to norm-setting in the field of information and communication. The statutes of both organizations contain injunctions to act to protect and promote freedom of expression and freedom of information. Article 1.2 of the UNESCO Constitution states, for example:

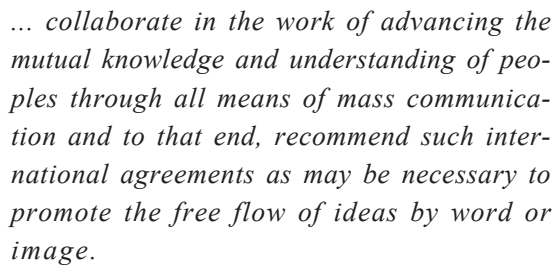

This commitment was acted on as early as 1948 , when the United Nations convened an international conference on information. International law in the area of information and mass media started with the founding of the UN and UNESCO. From the start, the work on information and the media was closely related to the organizations' work on human rights. A rapid pace of technological development in communications raised the need for international regulation, e.g., with respect to the use of space for communications satellites. As a consequence, information issues were politicized, a development that had a significant impact on UNESCO's subsequent work relating to the sector.

In its early years UNESCO experienced obvious tensions and some friction between industrialized and developing countries. The former emphasized UNESCO's norm-setting function, whereas developing countries emphasized the organization's assistance programs. Development assistance was directly related to the development process as practiced according to the modernization paradigm. Thus, it was natural in the late 1960s and early 1970s for critics of the modernization paradigm to voice their criticisms in connection with discussions of assistance. It was, however, UNESCO's normsetting function that subsequently provided the venue for discussions of the principles of a new international information order.

\section{International Agreements Relating to Information and Communication 1945- 1979}

International agreements, treaties-conventions, declarations and resolutions relating to information and communication that were adopted by the UN General Assembly and UNESCO General Conferences make up an important part of any history of the strivings for a new international information order. No less than 41 conventions and declarations (and six nearly completed drafts) saw the light of day in the postwar period up to 1980 . They focus on the legal status of various elements in mass communication and specify objects for regulation on a multilateral basis. They may be seen as attempts to establish a certain order concerning the roles of information in the international political system. A study of the many documents allows us to take readings of power relationships and the views on information and communication that prevailed at given points throughout the 35-year period.

More precisely, the 41 documents comprise eight treaties and conventions, six declarations and 27 resolutions. Two out of three were adopted by the General Assembly. It was not until the 1970s that UNESCO made its debut as a setter of norms. The texts deal with seven topics: rights and freedoms with regard to information; free flow of information; communications satellites (regulation of media uses); development of third world countries; peace-security-propaganda; discrimination; and a new world information and communication order. The largest number of agreements were adopted in the areas of rights and freedoms, peacesecurity-propaganda, development of third world countries, and free flow of information.

The documents issuing from the United Nations tend to focus on international legal aspects, whereas the resolutions emanating from UNESCO tend to focus on measures intended to promote a free flow of information. Three conventions have their origins in agreements arrived at during the period: the Declaration of Human Rights of 1948 led to two conventions in 1966; a resolution on "false and distorted reports" was incorporated into the convention on "international right of correction"; and resolutions on peaceful uses of outer space in 1961 and 1962 were incorporated into a declaration in 1963 and, ultimately, the Outer Space Treaty of 1967.

Major efforts were made in the 1940s and 1950s to bring a convention on freedom of information into being, but agreement on the issue remained out of reach. On the whole, however, we see the rudi- 
ments of a body of international law pertaining to information and communication emerging during the period.

One may also classify the agreements chronologically:

- 1945-1959: freedom of information and development assistance

- 1960-1969: new communications technology prompts regulation

- 1970-1979: prevailing principles are challenged.

Many of the documents contain elements that portend the subsequent demand for a New World Information and Communication Order.

\section{5-1959: Freedom of Information and Development Assistance}

Issues relating to freedom of information and 'free flows' of information predominated in early years. The concerns were mentioned in the Charters of both the United Nations and UNESCO. Both issues are expressions of the East-West confrontation known as the Cold War, which of course obstructed progress in the area, despite numerous draft conventions. Development assistance to third world countries and the evils of propaganda received a lot of attention in this context.

The agreements that were reached in these years were imbued with the views of the industrialized, primarily Western, parts of the world. Two factors explain this. The UN had 50 charter members, UNESCO had 20. This clearly influenced the normsettting function. Secondly, if it is surprising that such documents as the treaties of Beirut (1948) and Florence (1950) on the free flow of information could have originated in UNESCO, we should recall that the Soviet Union did not participate in UNESCO until 1954.

\section{0-1969: New Communications Technology Prompts Calls for Regulation}

The decade witnessed significant developments in communications technology, particularly communications satellites. There was a widely perceived need to regulate the technology on an international plane. In the span of seven years, the General Assembly was able to adopt two resolutions, a declaration and, finally, a treaty on the use of outer space. Issues relating to satellites also gave rise to heated debates relating to the free flow of information between East and West in UNESCO in the late 1960 s, but without resulting in an agreed document.
The UN extended its role as aid donor vis-à-vis the poor countries of the world. The documents are formulated from the wealthy countries' perspective. Another issue that surfaced during this period was racial discrimination; a convention on 'the elimination of all forms of racial discrimination' was adopted in 1965. All seven texts from this period were adopted by the UN General Assembly.

\section{0-1979: New Perspectives and Challenges to Prevailing Principles}

The principle of 'free flow' was debated more and more. The world had changed quite dramatically since the end of the war. Many former colonies were now independent nations. In the span of roughly a decade in the 1950 s and 1960 s no less than 85 countries were born. The fledgling nations were anxious to protect their national and cultural sovereignty, which represented a new perspective on the issue of free flows of information. Meanwhile, new technology - not least satellite communication - changed the nature of world communication itself. The 1972 UNESCO General Conference adopted a resolution proposed by the Soviet Union on setting out Guiding Principles on the Use of Satellite-Broadcasting for the Free Flow of Information, the Spread of Education and Greater Cultural Exchange. The vote was 55 in favor and 7 opposed, with 22 abstentions. The USA, which opposed the resolution, found itself outvoted. Thereafter, the focus of the debate in UNESCO shifted to media and cultural imperialism and its consequences. The debate swelled and may be said to have preoccupied UNESCO through the 1970s. In this period, the West frequently found itself in the minority as newly independent nations often sided with the Eastern bloc.

The UN and UNESCO produced four declarations and sixteen resolutions during the period. Nearly half of them emanated from UNESCO General Conferences, a testimony to the emergence of the organization as a forum in the area of information and mass communication. No treaties or conventions were forthcoming, however. The Cold War continued, but was modified on some issues by a new North-South dialogue. West and East were no longer the only actors on the stage. Representatives from developing countries coordinated their activities and were able to influence both the content of documents and agreements and the number of agreements reached. Seven of altogether nine resolutions on development in third-world countries between 1945 and 1979 were adopted in the 1970s. 
'Decolonialization', in both political-juridical and economic and cultural senses, had supplanted 'development assistance' as the focus of debate. In other words, earlier documents were seriously challenged. New principles and views were put on the agenda. The confrontations were innumerable, particularly in the work on a mass media declaration, which after much anguish, was adopted in 1978 . This work on media issues occupied UNESCO nearly a decade.

In early 1974, UNESCO's Director-General called on twelve experts to put together a preliminary draft of a declaration on mass media, more precisely, a Declaration on Fundamental Principles concerning the Contribution of the Mass Media to Strengthening Peace and International Understanding, to the Promotion of Human Rights and to Countering Racialism, Apartheid and Incitement to War. The aim was to formulate overall guidelines for the role of mass media in the international system.

When the draft came up for discussion in the Fall, the confrontation between the USA's commitment to 'free flow of information' and the Soviet Union's commitment to state control came to a head. At the same time, several of the developing countries criticized the concept of 'free flow', characterizing it instead as a 'one-way flow' and an expression of imperialist ambitions. Here, the EastWest conflict was displaced by a confrontation between North and South. Treatment of the Declaration on Fundamental Principles was postponed.

Efforts were also made to establish the concept of a 'right to communicate'. The idea was to establish an overarching principle, under which problems relating to mass media might be analyzed and corrective measures proposed. Sweden introduced the concept, coined in 1969 by Jean d'Arcy of France in the context of new communications technology, at the UNESCO General Conference of 1974. After lengthy discussion and numerous amendments a resolution on the 'right to communicate' was adopted.

The General Conference of 1976 also failed to produce a declaration on mass media. At one point several Western delegates left the meeting in protest. Newly appointed Director-General AhmadouMahtar M'Bow was instructed to work out and present a revised draft to the next General Conference, in 1978. Mr. M'Bow worked hard to formulate an acceptable draft, as the impasse had brought nearly all other work at UNESCO to a halt, but the draft proved unacceptable to most member countries as it included an argument for state influence over the media. The draft went into committee and emerged in a markedly diluted version that could, finally, be adopted. The feature of the resolution was a frank qualification of 'free flow of information'; the phrase was replaced with "a free flow and a wider and better balanced dissemination of information". The resolution also affirmed that the General Conference was
[c]onscious of the aspirations of the developing countries for the establishment of a new, more just and more effective world information and communication order (Declaration on Fundamental Principles Concerning the Contribution of the Mass Media to Strengthening Peace and Interna- tional Understanding, to the Promotion of Human Rights and to Countering Racialism, Apartheid and Incitement to War, 28th No- vember 1978, UNESCO, Paris).

Thus, the decade ended with documented acceptance of a fundamental rethinking of the principles to govern information and communication on an international plane.

When third world countries lodged their demand for a new international information order in the international arena, it was in the light of the role UNESCO played as a source of development assistance and as a setter of norms in the economic, social and cultural sectors. UNESCO was an instrument in a concerted reform effort. At the same time, the developing countries were dependent on UNESCO's assistance, for literacy training, education and development of the media sector. The question presents itself: What exactly did a 'new information order' mean? What did the third world hope to achieve?

\section{Third World Countries' Demand for a New International Information Order}

\section{The Non-Aligned Countries a Motor Force}

The non-aligned countries tabled their demand for a new international information order in the mid1970 s as an extension of already voiced demands for a new world economic order. Although the nonaligned countries could hardly be considered a unit in terms of ideology or political-economic systems and as a group had leanings toward both of the major blocs, they maintained a remarkably united front in relation to the NWICO issue.

The geopolitical changes that took place in the 1950 s and 1960 s when many former colonies at- 
tained their independence led to the emergence of a third force alongside the capitalist ('first world') and socialist ('second world') blocs. The concept of a 'third world' was coined in 1955 at the milestone Bandung Conference (Indonesia) of some thirty Asian and African states. The conference adopted several resolutions of historical significance: on the abolition of colonial rule, on the realization of democratic self-determination, on disarmament, and on economic and cultural cooperation. The Bandung Conference was the first joint manifestation undertaken by the new countries of Africa and Asia, and from it issued a movement of non-aligned countries that aspired to be 'a third force to act as a buffer between capitalism and communism' (Sing \& Gross 1984:446).

What the non-aligned countries meant by a 'new international information order' can be extracted from the documentation of the movement's meetings from the period between 1973-1980. ${ }^{2}$ The documents from the meetings that concern information and communication have the character of political 'position statements'; they resemble statements of foreign policy and doctrine that we find in the field of international politics. They are generalized (as opposed to specific), declare a definite point of view or posture in relation to the issue at hand, and an explicit world-view. At the same time, the statements form a sort of bridge between ideology and concrete action. It is sometimes difficult to discern specific policy objectives, guiding principles concerning how to go about realizing those objectives, or proposed solutions. What we have to work with are discussions of the role of mass media and information in the development process, national media structures and media policies versus international media structures and international regulations/policies, which touch on regional aspects and flows of media products as well as the thirdworld countries' relations with the industrialized part of the world.

\section{Critique and Demands}

The non-aligned countries discussed issues relating to mass media for the first time at their conference in Algiers in 1973, i.e., some years before they formulated and raised their demand for a new international information order. That the demand for reform of the world communications system arose out of the non-aligned camp was hardly sheer chance. A prime factor was the tumultuous change that was taking place in the world oil market. Oil flowed pri- marily from the third world to the industrial world, and the prosperity of the industrialized world depended heavily on the third world. Still, companies based in the USA, Great Britain and The Netherlands controlled the world oil market. All this changed (albeit not permanently) when the thirdworld countries whose oil reserves were exploited began to act in concert. The 'OPEC Crisis' or 'Fuel Crisis' of 1973, which brought a sharp rise in the price of petroleum products, broke a position of near-total dominance that the USA had enjoyed for over a century and won the non-aligned countries an unprecedented bargaining position (Bjereld 1989, Karlsson 1993). The countries of the third world had already voiced demands for a new world economic order at the start of the decade. It was in their interests to reform the structural factors that caused economic imbalances and injustices in the international system, yet up to now the countries had not been able to coordinate their efforts. Only after the success of OPEC (Organisation of PetroleumExporting Countries) and with the acquisition of greater diplomatic finesse were they able to form and maintain a more or less united front (cf. Bartelson \& Ringmar 1985).

In 1974, the United Nations adopted The Declaration on the Establishment of a New International Economic Order. In it, the prevailing order was characterized as one of "inequality domination, dependence, narrow self-interest and segmentation," whereas the new order would be founded on the principles of "equality, sovereign quality, inter-dependence, common interest and cooperation among states, irrespective of their economic and social systems" (Declaration on the Establishment of a New International Economic Order, 1st May 1974, New York). The declaration may be seen as a frontal ideological challenge to the status quo, that was generally termed 'liberal' (in a classical sense). A new international economic order presumed a reorganization of the international economic system (Ellingsen $\&$ Tunold 1984). National independence from the colonial powers was a strictly political-juridical matter; it was with the demand for a new economic order that the countries called attention to the neocolonialism of the prevailing world economic system and demanded reform (Blomström \& Hettne 1981). In practice, the countries demanded fair terms of trade, economic assistance, and access to Western technology.

Information was first brought up in the context of a 'new international order' at a meeting of the non-aligned countries in Tunis in 1976: 
Since information in the world shows a disequilibrium favouring some and ignoring others, it is the duty of non-aligned countries and other developing countries to change this situation and obtain the de-colonization of information and initiate a new international order in information ... . (Report of the Committee, The Non-Aligned Symposium on Information, Tunis, 1976)

At a minister-level conference some months later in New Delhi, the Ministers of Information of the non-aligned countries put it this way:

The Conference ... stressed that the decolonization of information is essential for these purposes and that the establishment of a New International Order for Information is as necessary as the New International Economic Order. ... (Declaration of the Ministerial Conference of Non-Aligned Countries on Decolonization of Information, New Delhi, 1976)

The demand for a new international information order was an outgrowth of third-world resentment of the imbalances in international news flows, as summarized in the phrase, 'one-way-flow'; the lack of respect for third-world peoples' cultural identity that such imbalances reflected, the monopoly positions of transnational communications corporations, which were perceived as a threat to the countries' national independence; and the inequitable distribution of communications resources in the world. These complaints were hardly new, but having achieved nationhood, the countries could now act to protect their national sovereignty and cultural identity.

Numerous academic studies carried out in the 1970s confirmed these complaints. News flows between the industrialized parts of the world and developing countries, or as many expressed it, between north and south, were far from balanced. International systems of communication were designed to serve the interests of the industrialized countries, and developing countries had no alternative but to use them. A handful of transnational corporations controlled the markets for news and communications technology. National media systems in the developing countries were poorly developed; many were state-controlled. Generally speaking, the media were weak and could neither supply their own countries with national news nor gather news from abroad. As a consequence, they were heavily dependent on international news services. The news these services carried was primarily commerce-oriented or reported events of a transient nature in per- sonalized and dramatized renditions. (Nordenstreng \& Varis 1974; Bishop 1975; Harris 1976; Varis \& Jokelin 1976; Höhne 1977, Tunstall 1977; BoydBarret 1980; i.a.)

\section{'The Four Ds'}

The documents relating to mass media and information that emanated from the meetings of non-aligned countries in the latter part of the 1970s indicate that the concept of a new international information (later also communication) order implied far-reaching reforms of the existing order, including all kinds of information - political, social, economic and technical; all the media - press, radio, TV, böcker, film, data banks, etc.; and all kinds of communications technology: communications satellites, cable$\mathrm{TV}$, telecommunications, including the price and rate control. That is to say, the proposals covered far more than content and the direction of flows and extended well into the organization and control of structures in the sector.

Four cornerstones emerge out of the material; they were referred to as 'the four Ds' (cf. Nordenstreng 1984). They represent themes that recur time and again in the discussions of the new order. 1. News flows are castigated as "one-way flows", and measures to ensure a more equitable balance of news flows between countries are demanded (Democratization). 2. The 'one-way flow' and misrepresentations are interpreted to reflect a lack of respect for the countries' cultural identities, a matter of great importance to the non-aligned countries (Decolonization). 3. The monopoly status of transnational corporations in terms of communications technology is perceived as a threat to national independence (Demonopolization). 4. The vital role of mass media in the development process is underlined, and the non-aligned countries join together to demand a more just distribution of communication resources in the world (Development). Thus, the demands were broad and fluid and partly overlapping; they describe different aspects of the problem complex.

Several of the documents of the non-aligned countries contain lists of recommendations as to how the countries should go about their work, on national, regional and international levels, to achieve a new information order. A systematic study of the documents in relation to 'the four Ds' reveals the implications of the new international information order, from the point of view of the non-aligned countries. 


\section{Democratization}

This first cornerstone is the most comprehensive. Four central demands can be discerned:

The right of people and individuals to acquire an objective picture of reality by means of accurate and comprehensive information as well as to express themselves freely through various media of culture and communication.

The right of every nation to participate, on the governmental and non-governmental level, in the international exchange of information under favourable conditions in a sense of equality, justice and mutual advantage.

The responsibility of various actors in the process of information for its truthfulness and objectivity as well as for the particular social objectives to which the information activities are dedicated.

Guarantees for and the necessary protection of journalists and other factors of information in the performance of their mission, and the responsibility of journalists in the performance of this mission.

These four points are closely related to the then ongoing debates in UNESCO on 'free flow of information' and the conditions under which journalists operated. They are phrased with reference to the international situation, while democratization on the national level is largely glossed over.

\section{Decolonialization}

The second cornerstone consists of two subthemes. First, we have passages that highlight self-determination, national independence, cultural identity, and so forth:

The fundamental principles of international law, notably self-determination, sovereignty and noninterference.

The right of every nation to protect its national sovereignty and cultural identity.

The right of each country to the observance of its interests, aspirations, and its political, moral and cultural values.

These texts refer to international law, and some concepts resemble the rhetoric of the dependence paradigm. Cultural identity is also assigned key importance.

Second, we have themes that invoke the demand for a new world economic order. Here, too, the rheto- ric is reminiscent of the dependence paradigm. In more concrete terms, it has to do with the assignment of radio frequencies, access to frequencies on geostationary satellites, and telecommunications infrastructure.

\section{Demonopolization}

The third cornerstone refers to another prime topic of debate in UNESCO of the 1970s, namely, the operations of transnational corporations:

The right of every nation to develop its own independent information system, in particular by regulating the activities of transnational corporations.

This item might well have been included under the preceding heading, but the emphasis put on 'demonopolization' in the documents merits a heading of its own. That emphasis also reflects the degree of influence the dependence paradigm exerted. The issue was discussed both on the international level, through the demand for a new world economic order, and on the national level, through proposed regulation of transnational corporations in third-world countries.

\section{Development}

Central features of the fourth cornerstone are the following three items:

The right of every nation to develop its own independent information system.

The imperative of a more equitable distribution of information media.

Adequate professional training for journalists including those working in indigenous languages.

The documents are most specific in relation to this theme. Here we find numerous exhortations directed to the industrialized countries: "adoption of national communication policies," "define a new concept of news not based on sensationalism...," "multiply exchange agreements among the countries of the third world," "consolidate and develop the infrastructures of information," "promote national agencies and POOL," "creation of regional information systems," "creation of centres for the training of journalists in the developing countries," etc.

Key elements are the necessity of national communication policy, the development of infrastructures, the establishment of national news services and regional news exchanges, journalism education, technical collaboration between regions and, not least, a will to "use horizontal cooperation, aid and 
solidarity between developing countries as the main instrument of the independence in information". Mass media, news media in particular, and most of all the press, are accorded a central role in the development process. The measures mentioned in the documents all refer to conditions in the third world, but the question acquires international scope because of the countries' need of development assistance from international organizations and the developed countries:

\section{... the obligation of the international organ- izations to assist the non-aligned countries towards the emancipation and developmet of their national information systems ...}

All in all, the content of a NWICO is formulated on the level of abstractions. The demands are not specified beyond a few key sentences under each cornerstone. This reflects how difficult the countries found it to agree on concrete measures. Yet the documents leave no doubt that the goal is a truly new international information order. Decolonialization is paramount and, ultimately, radical changes in global power relationships are implied.

Many of the themes are formulated on the macro level. We find many more references to "the right of every nation" (national sovereignty, self-determination, cultural identity, relations between nations) than to individual rights and freedoms. Issues relating to mass media and news flows take priority over other forms of communication. A number of problems are elevated to the international level, although they actually concern issues of a national character. They are discussed in an international context. The key passages noted here clearly indicate the desired direction: a rejection of the modernization paradigm in favor of self-determination, national independence, cultural identity and democratic flows of information between nations.

Thus, the documents of the non-aligned nations represent the contours of a new third view of development, having four main principles: 1. Development based on self-determination and cultural identity, 2. The recipient's control over development asistance, 3. International perspectives, and 4. Regional cooperation.

\section{UNESCO and the Demand for a New International Information Order}

\section{The MacBride Commission}

The demand of the non-aligned countries for a new international information order in UNESCO brought tensions to a head at the organization's General Conference in 1976, where the formulation of a declaration on mass media topped the agenda. The nonaligned bloc were partly successful, but no declaration was forthcoming from the conference. Instead, a commission, The International Commission for the Study of Communication Problems, known as the 'MacBride Commission', was appointed to study all manner of problems of communication in the world. One of its chief tasks was to

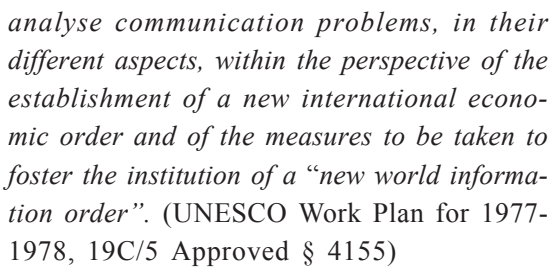

This marked the start of a new phase in the international discussion of mass media and information issues. It would turn out to be of decisive importance for their treatment in UNESCO. Also, the appointment of the Commission represents at least some acceptance of the challenge to the status quo on the part of the international political system.

UNESCO used the concept of a "world information order" rather than an "international information order". The change in wording was made on the initiative of the Western countries, who wished to make the connection to the demand for a new economic order less explicit. The word "international" connotes relations among nations, whereas "world" prompts associations to global cooperation more generally, with concepts like "the global village" and "world government" (Rosenau 1969, Holsti 1967).

Director-General M'Bow formulated the Commission's brief or terms of reference in four points:

(a) to study the current situation in the fields of communication and information and to identify problems which call for fresh action at the national level and a concerted, overall approach at the international level. The analysis of the state of communication in the world today, and particularly of information problems as a whole, should take account of the diversity of socioeconomic conditions and levels and types of development;

(b) to pay particular attention to problems relating to the free and balanced flow of information in the world, as well as the specific needs of developing countries, in accordance with the decisions of the General Conference; 
(c) to analyse communication problems, in their different aspects, within the perspective of the establishment of a new international economic order and of the measures to be taken to foster the institution of a 'new world information order';

(d) to define the role which communication might play in making public opinion aware of the major problems besetting the world, in sensitizing it to these problems and helping gradually to solve them by concerted action at the national and international levels. (Many Voices, One World, p 42)

As noted in the Commission report, the nomination of its members was "guided by the demands of pluralism and the need for unity and homogeneity; by the need to ensure the experience and qualifications, involvement of currents and thoughts, intellectual trends, cultural traditions, and the diversity of economic and social systems in the major regions of the world" (Many Voices, One World, p 295).

The Commission was chaired by Irish politician, diplomat and Nobel laureate Sean MacBride. The composition of the commission aroused much discussion from the start. ${ }^{3}$ Only one of the countries invited to participate declined the invitation, namely, China. The individuals were chosen on the basis of personal merits and would represent only themselves. Six of them, however, were politicians of national stature, and five others were active in politics. It is likely that these members may have regarded themselves as representatives of their respective countries. Three of the Commission were academics; two had been imprisoned for their views.

The MacBride Commission also engaged a number of external scholars and experts to produce specialized reports on aspects of the Commission's work. Nothing like this on this scale had ever happened before. The studies ranged from conceptual analyses to statistical compendia, surveys of national media legislation, and bibliographies. They were reported in roughly 100 publications. Thus, the MacBride Commission had a major impact on scholarship pertaining to international communication, as well.

A group of people were asked to define the concept of 'a new international information order', and the definitions were published in the commission's report series. Dutch communication researcher Cees Hamelink, wrote, for example:

Information as a national resource is a liberating force in the economic and cultural emancipation of a country, if its exploitation is guided by the principles upon which a new ordering of international economic relations is based (Hamelink 1979, p 6).

Hamelink defined a new international information order as:
an international exchange of information in which states, which develop their cultural sy- stem in an autonomous way and with complete sovereign control of resources, fully and effectively participate as independent members of the international community (Hamelink 1979, p 8).

Many of the other definitions solicited by the MacBride Commission were quite in line with Cees Hamelink's proposal, which in turn paralleled the arguments advanced by the non-aligned countries.

\section{The Report of the MacBride Commission}

The phrase, "new world information order", which was used in the terms of reference of the MacBride Commission, was rather short-lived within UNESCO, being used only two years. In the final text of the mass media declaration that was adopted in 1978, the wording is "a new, more just and effective world information and communication order". One migh interpret the change as a further adaptation to the position of the Western countries in that the new wording may be taken to mean not a totally new order, but an improvement of the status quo ante. The addition of "communication" may be seen as an attempt to encourage thinking about information flows, etc., as processes rather than phenomena. These shifts are also present in the title of the Commission's final report: Many Voices, One World. Communication and Society, Today and Tomorrow. Towards a New, More Just and More Efficient World Information and Communication Order, which was submitted to UNESCO's Director-General in Spring 1980.

The volume consists of five parts. The first four report the findings of studies in four areas: 1) "Communication and Society" (historical and contemporary perspectives and the international dimension), 2) "Communication Today" (means of communication, expanding infrastructures, concentration, interaction, participants, disparities), 3) "Problems and Issues of Common Concern" (flaws in communication flows, dominance in communication contents, democratization of communication, images of the world, the public and public opinion), 
4) "The Institutional and Professional Framework" (communication policies, material resources, research contributions, the professional communicators, rights and responsibilities of journalists, norms of professional conduct). The Commission had the ambition to treat their subjects from historical, socio-economic, cultural and political perspectives. The report treats all kinds of information and communication, from interpersonal communication to mass communication and digital communication from local, national and international points of view. The fifth part of the book, "Conclusions and Recommendations" offers some eighty policy recommendations of problems studied.

The Commission report stresses that it is not only about developing countries, but about the whole of humanity, because unless the necessary changes are made in all parts of the world, it will not be possible to attain freedom, reciprocity or independence in the exchange of information worldwide. The Commission confirmed the persistence of imbalances in news and information flows between countries and marked inequalities in the distribution of communication resources. The Commission agreed about the necessity of change and found the current situation "unacceptable to all" (Many Voices, One World 1980:xviii), but they were unable to agree on a definition of the concept of a 'new world information and communication order'. The closest they came were these few lines in Chairman Sean MacBride's preface:
...the 'New World Information and Commu- nication Order' may be more accurately de- fined as a process than any given set of con- ditions and practices. The particulars of the process will continually alter, yet its goals will be constant - more justice, more equity, more reciprocity in information exchange, less dependence in communication flows, less downwards diffusion of messages, more self- reliance and cultural identity, more benefits for all mankind. (Many Voices, One World, 1980:xviii).

Although it was part of the Commission's remit, no real attempt is made to specify the links between a new world economic order and a NWICO.

International flows of information are discussed in part three of the report, in connection with current problems and in the sections relating to the rights and responsibilities of journalists. Here the discussion invokes a number of concepts that already had won acceptance in UNESCO. The Commission links, for example, 'freedom of the press' to the principle of 'the right to communicate' and to the various conventions on human rights adopted by the United Nations. Links are also established to concepts like 'balanced flow of information' and 'free access to the media'. In this letter connection, the report states:

\section{Despite many disputes about the validity of such criticisms it seems irrefutable that 'free flow' between the strong and the weak, the haves and the havenots, has had undesirable consequences for the latter, and hence at the international level for the developing coun- tries (Many Voices, One World, 1980: 141f).}

For the first time ever, a UNESCO document plainly stated that a few transnational companies controlled the international information system and that their control posed a threat to the cultural integrity and national independence of many countries. In extension, this dominance is seen to pose a threat to a new world economic order. The Commission perceives corporate dominance to be a consequence of the postwar doctrine of 'free flow of information'. Furthermore, the report baldly describes international information flows as one-way and vertical (top-down). Long-term measures to improve the availability of international news are discussed in terms of the working conditions of journalists, professional skills and attitudes, and the views of governments. A section entitled "The Technological Dilemma" discusses issues relating to new technologies. Here, the Commission did not report a single, unequivocal view. The commercialization of information is harshly criticized, as is the expansion of advertising markets. The Commission stressed the importance of the social function of information. An important theme in the report throughout is, for that matter, an emphasis on the societal roles of information and the need for democratization of communication flows.

The sharp differences that had characterized the discussions throughout the 1970s were also present in the MacBride Commission. Considering that it consisted of 16 members representing different ideologies, different political, economic and cultural systems, different geographical areas, it is surprising that the Commission managed to reach agreement on as many points as they did. In his Foreword to Many Voices, One World, Sean MacBride writes that the members "reached what I consider a surprising measure of agreement on major issues, upon which opinions heretofore had seemed irreconcilable" (xviii). Due to differences in the group, the report does not offer any specific proposals re- 
garding communication policy principles. On the other hand, it does offer a good number of recommendations and suggestions with a view to reforming the prevailing structures in world communications. A majority of those who commented on the report, including many who were essentially critical, agreed that Many Voices, One World was the most thoroughgoing document of its kind on communication to have been produced in UNESCO's name (Carlsson 1991).

This very brief recap of the findings of the MacBride Commission suggests that the third world's critique of the prevailing order was heard and gained some measure of acceptance with regard to the pattern of information flows and the dominance of transnational news and media corporations as a threat to cultural integrity and national independence. But it is only when we analyze the Commission's conclusions and recommendations that we can truly assess the degree of acceptance the third world's views on international information and communication attained.

\section{The 82 Recommendations of the MacBride Commission}

\section{An Approach}

Fundamental to the demands of the non-aligned countries for a new international information order was the idea of greater regulation of the media system on an international level. The task of the MacBride Commission was to study the problem area and consider solutions. In its final report, the Commission proposed a series of measures with a view to creating such a new order. The categories in which the proposals are arranged are quite descriptive of the contents: "Strengthening Independence and Self-Reliance"; "Social Consequences and New Tasks"; "Professional Integrity and Standards"; "Democratization of Communication"; and "Fostering International Cooperation".

Questions to be asked are: What kinds of changes does the Commission propose in order to achieve a NWICO? To what extent did the demands of the third world gain acceptance?

The recommendations have been analyzed with respect to the ideas implicit in them - a kind of critical analysis of political ideas (Vedung 1977). The analysis identified subject areas the recommendations treat (and do not treat) and assessed the consistency of the recommendations, their relevance and potential to achieve change. Four perspectives have been perceived:

\section{A Communication perspective}

The MacBride Commission was asked to study all forms of communication on the level, including developments in communications technology. How do the recommendations reflect this? How does the Commission interpret 'communication'? To gain a clearer idea of what aspects of the prevailing order the MacBride Commission sought to change it is interesting to examine the links in the communication process that the Commission emphasizes. Where are changes called for? Here it is useful to distinguish between the media institution, meaning "the principles, laws, conventions and instruments for regulation that society has at its disposal", that is to say, the media on a societal level; the media organization, which executes the production and distribution functions, i.e., the media companies within which production takes place; and media audiences (McQuail 1984, 1987).

\section{A development perspective - the roles of mass media in society}

The starting point here is theories of the role of information and communication in the development process and the ideas in the third-world countries' demands for a new international information order. On the basis of theories of the social purposes of the media, the following five functions are identified: information, interpretation, continuity, entertainment and mobilization (McQuail 1984, 1987). Some functions overlap; the first and fifth have to do with change, whereas the middle three concern integration (McQuail 1984:75).

\section{A third-world perspective}

Here the focus rests on 'the four D's'. To what extent do the recommendations of the Commission support the demands for Development, Democratization, Decolonization and Demonopolization? These demands call for measures not only in the developing countries but, perhaps even more so, in the developed countries. Where does the Commission call for changes? Is it conditions in the developing countries, in the developed countries? Or, are the issues discussed in a global perspective? Are any actors specified? Ultimately, it is a question of the extent to which the recommendations call for national, regional or international solutions.

\section{A practicability perspective}

To what extent are the recommendations practicable? The following categories indicate different degrees of specification and action orientation: 1) systems level (overarching, general goals, indicate gen- 
eral direction); 2) strategic level (action-oriented, but general); 3 ) implemantation level (application, concrete solutions, outlined step-by-step, specified actors). (cf. Petersson 1964)

\section{The Recommendations}

The measures the MacBride Commission recommended to bring about a "new more just and efficient world information and communication order" may be described in four points:

1. The development of third-world countries so that they become truly independent and self-reliant and develop their cultural identities

Proposed means to reach these goals include: tailoring national communications policies to suit the conditions in the country, building infrastructure, equitable distribution of common global communication resources, limits on the activities of transnational corporations, preferential treatment of non-commercial media, balanced flows of technical information.

\section{Better international news gathering and better conditions for journalists}

The Commission recommends ethical rules for the practice of journalism, improved journalism education, multiple news sources, observance of the Helsinki Agreement and the Geneva Convention.

\section{Democratization of communication (access and participation, the right to communicate) \\ Important measures here are guarantees of hu- man rights, acceptance of 'the right to communi- cate', abolition of censorship, editorial inde- pendence, limits on media concentration and monopolization, limits on the influence of adver- tisers on editorial policy/media content, atten- tion to the communication needs of women, children and minorities, and facilitation of hori- zontal communication.}

\section{Furtherance of international cooperation}

The measures in this last category aim to effectuate previous proposals through international cooperation: development assistance, support of regional fora and collaborative projects, e.g., NANAP, collaboration between professional organizations and within the research community, an international center for research and planning of information and communication.
The recommendations of the MacBride Commission with the aim of bringing about a more just and efficient world information and communication order focus almost entirely on conventional mass media. This, despite the fact that the Commission's terms of reference were much broader in scope. The importance of traditional communication is referred to in the introductory remarks accompanying the recommendations, but none of the recommendations concern traditional forms or channels of communication. Media technology is the only aspect besides mass media to be considered.

The recommendations are highly structure-oriented; most of them concern media institutions and media organizations. Fewer than a handful treat media content (advertising and news), and not many more than that concern media audiences (education in the development process, horizontal communication, the special communication needs of certain groups).

In a number of the recommendations the Commission assigns the media specific functions. The mobilization function is stressed in relation to development, the continuity function in relation to cultural identity, the information function with respect to news gathering, and both information and interpretive functions in relation to democratization of communication. Elements of both change and integration are present.

The document largely bears the stamp of a development perspective. The development of the countries of the third world is seen to have a key role in the work toward a NWICO. The greater part of the recommendations treat conditions in the third world, and taken together, most form a third paradigm of development. When it comes to measures relating to communication technology, the picture is more mixed and somewhat contradictory. Several of the recommendations fit in with a modernization paradigm, but a couple are more in keeping with the dependence paradigm. Neocolonialism confronts decolonization. On the whole, however, it is clear that the thirdworld countries receive more support for their four demands, the 'four Ds' than in any previous international document. Most support is expressed for development (national communication policy, building of infrastructure, journalism education) and decolonization (cultural identity), but there is support, albeit in more general terms, for democratization (just flows of information, the allotment of radio frequencies, satellite capacity, telecommunications) and demonopolization (regulation of transnational corporations), as well. A lot of emphasis is put on 
the right to communicate, defined as "the right to be informed, the right to inform, the right to privacy, the right to participate in public communication" at all levels - "international, national, local and individual" (Many Voices, One World, 1980:265+173).

The Commission regards these issues as national, whereas the non-aligned countries applied an international perspective. The Commission's proposals are nearly all national in focus. Furthermore, there are far more references to what developing countries should do than to what developed countries should do. At the same time there is, in the fifth part of the recommendations, an emphasis on development assistance and organs of international cooperation as sources of support to the third world, which strengthens the document's leanings toward a development perspective.

Most of the recommendations are formulated on the strategic level. Some are quite concrete, but few specify any actor. The actors specified are international organs, etc., that already have a regulatory framework. Thus, the key question of who should undertake the recommended measures remains unanswered. The forms of international cooperation outlined in the fifth part are not sufficiently specific. All in all, then, the extent of implementation is weak, which definitely limits the prospects of bringing about a new information and communication order.

Some recommendations are formulated on the systems level, and these are unfailing indications of the areas in which the Commission was unable to resolve its differences. Examples of this in the second part concern limiting the commercialization of media and strengthening cultural identities, while all of the recommendations in the fourth part, on democratization of the media, have this character. These are also the object of the most reservations on the part of individual commission members. At the same time, these recommendations are of the greatest importance in relation to the demand for a NWICO.

\section{From Regulation \\ of the International Media System to National Development Assistance}

\section{The Presentation of the MacBride Report at the UNESCO General Conference of 1980}

The report of the MacBride Commission, Many Voices, One World, was one of the main points on the agenda of the 21 st General Conference of UNESCO, held in Belgrade in 1980. As at the two preceding General Conferences, Nairobi in 1976 and Paris in 1978, mass media issues dominated. This was the first time, however, that UNESCO would debate the concept of a 'new world information and communication order', a NWICO. How would the international political system respond to the recommendations of the Commission? Would it prove possible to change the structure of world communications by means of political decision-making? In the following we shall consider the findings of an analysis of the debates and resolution that followed upon the report of the MacBride Commission. ${ }^{4}$

The general feeling before the General Conference was that the debate concerning the MacBride report would be heated and the confrontations many. This was not the case, however. Compared to previous debates on the subject, the discussions at the 21 st General Conference were both constructive and open, even if no major changes of position were to be noted. A majority of the speakers in Programme Commission IV Culture and Communication, where the MacBride Commission was debated, received the report favorably, which is not to say that there was no criticism. The political differences between East and West, North and South had not diminished.

The non-aligned countries pursued their agenda of a NWICO and criticized the dominance of the industrialized world in the area of communications and the marked imbalance of exchanges of information between countries and regions. The power of transnational corporations over the communication of ideas, messages, etc., and the threat that power implies for the countries' cultural identities were stressed. Many speakers from third-world countries spoke of the role media play in the development process. In this connection they supported the principle set out by MacBride Commission, that national communication policy should strive toward the same goals as the country's development policy. The nonaligned countries also lauded the MacBride Commission's support for the idea of democratization of the media. Many stressed the importance of developing the use of "small and local media".

The Eastern states emphasized the responsibility of mass media and their role in combatting racism, colonialism, imperialism and so forth. These speakers found the MacBride Commission too West-oriented. The delegates of the Eastern countries were remarkably restrained in this debate, compared to previous General Conferences.

The Western countries continued to stress freedom of information and freedom of expression and the rights of individuals. They expressed the hope 
that the MacBride report would be used "to promote democracy and freedom of communication, diversity and plurality of news production and access to a broad spectrum of sources". The strongest criticism of the MacBride Commission was raised by members of the Western 'bloc', with the USA and Great Britain the most outspoken critics. These two countries saw the document as militating against a free flow of information.

An emphasis on practical measures was widely supported, and many spoke in favor of a project proposed at a UNESCO Intergovernmental Conference in Paris the preceding Spring, namely, "a project for the establishment within the framework of UNESCO, of an International Programme for the Development of Communication" (Recommendation from Intergovernmental Conference for Communication Development, Paris 14th-21st April 1980, §3 CoS, 19, p 85; known as the 'DEVCOM Conference'). Nearly all the delegates were agreed as the need for greater communication capacity in the third world and that international cooperation was needed to develop infrastructures in the third-world countries. These were the aspects of the MacBride report that received the most attention.

To the surprise of many, Director-General M'Bow's document on the findings of the Commission were quite cautious and general. The passage, "no need for immediate actions at this stage," clearly signaled that the recommendations of the Commission would be let go by the boards, that no implementation would be forthcoming (DOC $21 \mathrm{C} / 85)$. But a majority of the speakers agreed that the Commission had fulfilled its task and regarded the report as a milestone in continued international discussions. There was also general agreement that the recommendations, while far from definitive, could be used as a framework of the construction of a new order.

In his closing remarks, the Chairman of the General Conference underlined the need of assistance in the field of communication. He also expressed the view that the debate had demonstrated the need for UNESCO to play an active role with regard to communication. He hailed the MacBride Commission report as a step along the way toward a new international information order that must be founded on 1) the "elimination of domestic and external barriers," 2) "pluralism of information," 3) "freedom of the press," and 4) the "free circulation of information, ideas and persons" (UNESCO, Records of the General Conference 1980, vol. 2).

Finally, the Chairman announced that a working group would be appointed to draft a resolution on the subject. Three drafts had been tabled: one from each 'bloc'. After protracted and difficult negotiations, consensus on a draft resolution was reached. Several countries, including Great Britain, the USA, Canada, Australia and Japan, asked that the reasons for their vote be recorded in the minutes. These largely revolved around the definition of 'a new world information and communication order'.

\section{A Draft NWICO}

The preamble of UNESCO Resolution 4/19 on the International Commission for the Study of Communication Problems is reminiscent of Article 19 of the Declaration of Human Rights and of Articles 19 and 20 in the International Convention on Civil and Political Rights. The first part of the resolution acknowledges the contributions of the non-aligned countries in the area of information and communication:
Noting the increasing attention devoted to communication problems and needs by other intergovernmental organizations, both regio- nal and international, notably the Movement of Non-Aligned Countries which, in the Dec- laration of the Colombo Summit (1976), stated that "a new international order in the fields of information and mass communication is as vital as a new international economic order' and, in the Declaration of the Havana Sum- mit (1979), noting progress in the develop- ment of national information media, stressed that "co-operation in the field of information is an integral part of the struggle for the crea- tion of new international relations in general and a new international information order in particular," ... (UNESCO Records of the Gen- eral Conference 1980, vol. 1, Res 4/19).

It was the first time such an acknowledgment was made by an international organ such as UNESCO. Several clauses referred to the work of the MacBride Commission, which is lauded as a valuable contribution to the study of problems relating to information and communication. Many problems were seen to have been defined, analyzed and constructive solutions to them proposed. The recommendations of the Commission, however, were deferred and filed among the preliminary documentation for UNESCO's Medium-Term Plan 1984-1989.

Some features of the recommendations are included in the resolution. Certain phrases in paragraph 10 highlight the need to develop information and communication: the drafting of national com- 
munication policy, developing infrastructure, democratization of the media. These three points are the most concrete points in the resolution. They refer primarily to the recommendations listed in the MacBride report under the heading, "I. Strengthening Independence and Self-Reliance" and the portion of "IV. Democratization of Communication" that pertains to human rights. Paragraph 13 of the resolution also refers to the recommendations (40 and 46) of the Commission concerning "improved international reporting". The resolution calls for the need for UNESCO to help enhance journalists' knowledge of other cultures and the economics and politics of other countries.

The essential content of the resolution is to be found in paragraph 14, where a couple of points outline the content of a conceivable new world information and communication order. The paragraph consists of three parts, a)-c). The first contains eleven points that provide a conceivable framework for a new world order; the second states that the new order shall be founded in international law; and the third points out that different countries will choose different solutions, according to their social, political, cultural and economic traditions and cir- cumstances. This latter point was empasized in the MacBride Report, as well.

It is quite clear that it was difficult to midwife the resolution, and particularly the catalogue of possible 'fundaments' of a new world order in paragraph 14, into being. One sign of the power struggle is the phraseology that introduces the eleven points in part a). The use of "could" instead of "should", as in b), is a sure sign that a NWICO is a process that the authors of the resolution have agreed to continue working on and one that may be based on the fundaments set out in the resolution (Nordenstreng 1984, Garbo 1984). Thus, the resolution assumed more the character of recommendations than calls to duty on the part of the signatories.

The fundaments outlined in paragraph 14 are even more general than the recommendations in the MacBride report. All eleven points in part a) may be traced back to the 82 recommendations of the Commission, but the language has been modified. The level of abstraction and the rhetoric both reflect the amount of diplomatic effort that went into forging agreement on the draft and, not least, of the lukewarm reception of the MacBride recommendations on the part of Director-General M'Bow -

Resolution 4/19 Adopted by the Twenty-first Session of the UNESCO General Conference, Belgrade, 1980.

$\S 14$. The General conference considers that

a) this new world information and communication order could be based, among other considerations, on:

i) elimination of the imbalances and inequalities which characterize the present situation;

ii) elimination of the negative effects of certain monopolies, public or private, and excessive concentrations;

iii) removal of the internal and external obstacles to a free flow and wider and better balanced dissemination of information and ideas;

iv) plurality of sources and channels of information;

v) fredom of the press and information;

vi) the freedom of journalists and all professionals in the communication media, a freedom inseparable from responibility;

vii) the capacity of developing countries to achieve improvement of their own situations, notably by providing their own equipment, by training their personell, by improving their infrastructures and by making their information and communication media suitable to their needs and aspirations;

viii) the sincere will of developed countries to help them attain these objectives;

ix) respect for each people's cultural identity and for the right of each nation to inform the world public about its interests, its aspirations and its social and cultural values;

$\mathrm{x}$ ) respect for the right of all peoples to participate in international exchanges of information on the basis of equality, justice and mutual benefit;

xi) respect for the right of the public, of ethnic and social groups and of individuals to have access to information sources and to participate actively in the communication process:

b) this new world information and communication order should be based on the fundamental principles of international law, as laid down in the Charter of the United Nations;

c) diverse solutions to information and communication problems are required because social, political, cultural and economic problems differ from one country to another and, within a given country, from one group to another. (UNESCO Records of the General Conference 1980, vol 1, Res 14/19) 
which countries like the USA and Great Britain greeted with some satisfaction (Goddard-Power 1984, Garbo 1984).

Development, strengthening of independence and self-reliance, cultural identity, democratization (access-participation) and the right to communicate were key concepts in the recommendations of the MacBride Commission. Of these key concepts, only 'development' and 'cultural identity' were included in the text of the resolution. The fundaments included in the resolution may be grouped according to their thematic content. First, there are incitements to remove various hindrances and negative effects (e.g., monopolization and concentration). Secondly, freedoms (of information, the press, journalists' rights and responsibilities, multiple sources). Third, a couple of more concrete points concerning development and third-world countries' need of development assistance. Finally, the concluding points are about cultural identity, the right to participate in international flows of information, the right of access to sources of information, etc.- all in all: aspects of the 'right to communicate', albeit the phrase is absent from the resolution. On that point no consensus could be reached.

The concluding paragraph of the resolution ( $\$ 15$ ) expresses a sense that UNESCO has hereby affirmed:

\section{...its willingness in its short-term and me- dium-term activities to contribute to the clari- fication, elaboration and application of the concept of a new world information and com- munication order ... (UNESCO Records of the General Conference 1980, Res 14/19).}

In all probability no resolution would have been forthcoming, had the Director-General insisted that the resolution be based on the 82 recommendations of the MacBride Commission. An emphasis on 'development' may be the factor that made consensus possible. Development and development assistance were also in focus in the creation of the International Programme for Communication Development (IPCD), which may be counted among the indirect results of the work of the MacBride Commission's work. The terms of reference of the IPDC were set out in a separate resolution, the preamble of which states:

....this international programme, aiming to increase co-operation and assistance for the development of communication infrastructures and to reduce the gap between various countries in the communication field, must form part of the efforts for the establishment of a "new, more just and more effective world information and communication order"... (UNESCO Records of the General Conference 1980, vol 1, Res 4/21).

Otherwise, the resolution consists of statutes, procedural rules, scope of activity (purpose). The tasks of the IPDC are set out in 14 points. These fall into four categories (Garbo 1984):
1. Development assistance - analysis of needs, planning and development of a national com- munication sector, development of infrastruc- tures, assistance in using communication in the development effort in economic, social and cultural spheres;

2. Coordination - to facilitate cooperation between actors in international communication development, to strengthen the cooperation between UNESCO and the International Telecommunication Union, to promote regional cooperation, e.g., between news services in the developing countries;

\section{Information - to gather information about needs and resources in the field of communi- cation, to evaluate cooperation between deve- loping and developed countries; and \\ 4. Funding - raising the financing necessary to carry out assistance, coordination and in- formation activities.}

Many delegates expressed their satisfaction over the institution of the IPDC. Delegates from the third world were particularly pleased. The draft from the DEVCOM meeting in Paris in early 1980, which preceded the IPDC resolution, was included in the resolution of the General Conference. It is a more farreaching document than the MacBride resolution, viewed from the point of view of the non-aligned countries. It contains rhetoric like 'safeguarding national sovereignty and cultural identity,' 'situations of dependence,' 'state of dependency of developing countries in the field of information and communication,' 'democratization of international relations in the field of information,' a 'need to establish a new information and communication order,' 'the fundamental contribution that the information media and mass communications can make to the establishment of a new economic order' - rhetoric that is much more in keeping with that of the non-aligned countries than either the MacBride Commission or the Western countries. Although the USA had advocated donor control and limited authority on the part of 
UNESCO at the DEVCOM meeting, the text emanating from the meeting was adopted in consensus, to the surprise of many observers (Nordenstreng 1984, Richstad \& Anderson 1981).

\section{The General Conference of 1980 - A Turning Point?}

As noted earlier, the 1980 General Conference was approached amidst mounting uncertainty as to the future of UNESCO. The third world's demands for radical reform of the prevailing information order were characterized by some in the West as a threat to the 'Free World', as 'Freedom under attack' (Fascell 1979). Many Western countries perceived the movement as an "effort by the Soviet Union and some Third World countries to foster government control of media under the guise of a New World and Communication Order" (Goddard-Power 1981:142). Meanwhile, fatigue was widespread within UNESCO, and many delegates felt that some change was necessary if UNESCO were to live on in keeping with its statutes.

Media issues had dominated UNESCO's agenda most of the 1970s, with wars of words and ideas being waged on two front lines: East vs West and North vs South. Both the USA and Great Britain threatened to leave UNESCO on repeated occasions. By 1980, there was a general will, among countries in all three blocs, to reach some kind of mutually acceptable compromise on issues relating to mass media in order to normalize the climate within UNESCO. One route toward agreement that won support in many quarters was an urge to take action. Strong support was expressed for the development program, IPDC, particularly among the Western countries, whose position was most probably tactically motivated (Goddard-Power 1984: 462, Nordenstreng 1984a:46). A commitment to practical development assistance might mollify the non-aligned countries, bring them to soften their demands, and reduce the intensity of ideological confrontations in international fora. This is not to say, of course, that some Western countries may have acted on sincere conviction (Svenska UNESCORådet 1980, Garbo 1984).

Even the Soviet delegation showed signs of a willingness to compromise. It had to do with the political repercussions of the country's invasion of Afghanistan the year before. The Soviet leadership was anxious to maintain good relations with Western Europe, despite the chill in relations with the USA
(Jonson 1985). As a consequence, the Soviet delegation was much more restrained at the General Conference of 1980 than in previous meetings. Moreover, a study of the proceedings of the General Conference suggests that Director-General M'Bow had decided to adopt the role of facilitator or arbitrator on issues relating to communication. Such a role is also suggested in his document pertaining to Many Voices, One World. This was an entirely new role for the Director-General, who was known for his militance and as a spokesman for the third world position. His posture at the 1980 General Conference may have been intended to improve a tarnished 'image' in the eyes of certain Western countries (cf. Gerbner et al. 1993, Nordenstreng 1989).

$\mathrm{Be}$ that as it may, there is no doubt that the General Conference of 1980 marked a breakthrough for the demands of the third world. Although the recommendations of the MacBride Commission were not debated, the work of the Commission had a palpable influence on the conference and its outcome in that a number of issues - such as the IPDC - had been aired and digested at intergovernmental meetings leading up to the General Conference. The Commission had cleared the path, so to say, which benefitted the third world countries in several respects. The ideas of the non-aligned countries had won recognition. UNESCO members were able to agree on several fundaments for a new world information and communication order, several of which corresponded with the intentions of the non-aligned countries. Surprisingly, even a clause on monopolization and concentration of the media won approval. The industrialized countries promised aid to help to build and develop communication systems in developing countries. One can take this as evidence that the third world advanced its position and that the concept of NWICO had attained some measure of acceptance. At the same time, the West put development and aid issues squarely on the agenda and managed to turn the focus away from their own roles and onto conditions in the third world countries. Some statements coincided with tenets of the modernization paradigm. The international dimension was diluted, as it had been in the MacBride Commission's work. Here we can perceive a crossroads for UNESCO on the horizon, a point where the organization would have to choose between continued work on a new information order and a more decided focus on development and aid issues. 


\section{Full Circle:}

\section{NWICO is Relegated to the History}

The UNESCO General Conferences 19821989: A Focus on Practical Measures

The inflamed debate that the issues of free flow of information and a new world information order aroused in the 1970s bore two concrete results at the 1980 UNESCO General Conference. Two resolutions were adopted, one a follow-up to the work of the MacBride Commission, and the other a move to set up IPDC, an international development program for mass communication. These two resolutions were to dominate UNESCO's continued work with communication. Here we shall look into what became of NWICO in the 1980s. How did UNESCO deal with issues relating to information and communication more generally? What traces of the work of the MacBride Commission are present in the programs of the 1980s? What were the consequences of the two resolutions adopted at the General Conference? An analysis of the discussions that took place in UNESCO after 1980 helps to answer our main question: What caused NWICO to be stricken from the international agenda? ${ }^{5}$

The MacBride resolution contained a skeleton plan for a new information and communication order in the world, but the recommendations of the Commission were referred to the planning of the coming six-year plan for 1984-1989, "Communication in the Service of Man," to be adopted at a specially convened General Conference in 1982. Although, the recommendations did not make any major imprint on the main program, some of the recommendations are visible in sections of the plan, most notably, in relation to the needs of developing countries to enable them to take part in international exchanges of information. The MacBride Commission had emphasized the right to communicate, but it had proved impossible to reach consensus on the concept at the 1980 General Conference. Two years later, however, it could be included in UNESCO's six-year plan. The communication rights of women and minorities, the conditions applying to journalists and information and communication technology are other areas in which reference is made to the recommendations of the Commission. At the same time, the general turn toward development efforts in third-world countries was reinforced.

Former differences among UNESCO members remained, but the direct confrontations were fewer than they had been in many years. But in retrospect it is clear that the tranquility was illusory and largely confined to the General Conferences. The issue of a
NWICO, as formulated in the MacBride resolution of 1980 was still a thorn in the sides of many Western countries. Particularly the USA and Great Britain were vehement and threatened to withdraw from UNESCO. A frontal assault on the idea of a NWICO was mounted in a declaration adopted by an international conference with representation from some twenty countries arranged by the World Press Freedom Committee inter alia in Talloire, France, in 1981. UNESCO was also criticized for inefficiency and for its having become 'politicized'. The prominence and influence of third-world countries in UNESCO in the early 1980 s, with many positions in the secretariat, a result of Director-General M'Bow's policies, was a constant source of friction (Bartelson \& Ringmar 1985).

The USA had additional complaints, as well. The foreign policy of the newly installed Reagan Administration differed markedly from that of the Carter Administration. The American UNESCO Council experienced a decided change of climate as cold war sentiments again gained currency. The reporting from the 1982 General Conference to the Reagan Administration was totally preoccupied with communication issues, and the work in UNESCO was perceived to limit the freedom of the press and to subordinate individual freedoms to the will of the collective (Bartelson \& Ringmar 1985, Gerbner 1993, Goddard-Power 1984, Harley 1981, Levin 1984, Mehan 1981).

The USA also mentioned UNESCO's work with NWICO among the reasons for their decision to leave the organization in 1984. Shortly after the American announcement, Great Britain, too, made it known that they were considering withdrawing, which they did the following year. These decisions were taken despite the fact that the heated confrontations expected at the 1983 General Conference did not materialize. Instead, communications issues were even more de-politicized and development assistance moved even further to the fore. The countries of the Eastern bloc continued to hold a decidedly lower profile than they had in the 1970s. In other words, the decisions to leave UNESCO came at a time when the will to reach consensus was exceptionally strong. The withdrawal of the two great powers dealt a major blow to UNESCO's budget and thus to the organization per se.

At the 1985 General Conference, after the USA left UNESCO, the non-aligned countries made a concerted effort to push for a NWICO, but their efforts were in vain. Their influence in international arenas had declined significantly in several respects, and at the General Conference of 1989, the concept 
of NWICO was stricken from the agenda once and for all. Even interest in the concept of the right to communicate cooled. Free flow was again in the ascendant. Despite these changes in UNESCO policy, neither the USA nor Great Britain showed any willingness to return to the organization.

The 1989 General Conference marked the ultimate failure of the non-aligned countries to bring about new principles for information and communication in the world. A political vision faded into history, displaced by an increasing focus on practical development assistance, a change that also imbued the communication program adopted at the Conference. Looking back to the 1960 s, we see that the issues relating to world communication had come full circle. UNESCO's role was once again that of donor.

During the 1980s, the IPDC (International Programme for Communication Development) came to symbolize the new emphasis on practical measures often synonymous with development assistance. Support for the Programme was virtually universal. In its early sessions several attempts were mounted to turn the IPDC into a forum of ideological debate, but IPDC Chairman Gunnar Garbo, a Norwegian, managed to hew to a practical line. The lodestars of the IPDC were, from the start, independence, self-reliance, and cultural identity - key concepts, all three, in the recommendations of the MacBride Commission. The developing countries retained a relatively strong position in the IPDC in early years.

Funding proved a problem, however. After the first two years in operation, Norway contributed roughly half of budget, while two-thirds of the other half came from the developing countries themselves, testimony to their great interest. In 1988, the IPDC extended some 13 million dollars to 332 projects. In early years, developing news services was in focus; in time, the focus shifted to education and professional training. The majority of projects were national, the rest regional.

In the years following Garbo's term of office, the IPDC grew increasingly bureaucratic and support for the Programme waned. Indeed, criticism hailed down on the organization. In short, the IPDC failed to realize the intent of the resolution that gave birth to it, namely, to develop media structures in the third world.

\section{Four Reasons for UNESCO's Change of Course}

After 1980, only one international agreement on information and mass communication was reached, viz., the agreement on "The Right to Communicate" adopted at the UNESCO General Conference of 1983. The only other resolutions pertaining to the area had to do with the development program, IPDC. This, if anything, confirms the change of climate and changed power relationships since the preceding decade, which saw no less than eight such agreements in the area adopted by UNESCO. The vehement debates about issues like freedom of information, the social responsibility of the media, free flows of information, news imperialism and, ultimately, a new international information and communication order may thus be seen to form an exceptional parenthesis in UNESCO's history to date. The issue of a NWICO was history, having been displaced by questions relating to development assistance. The reasons for this change of course may be summarized in four points.

\section{The MacBride Commission lends structure to the debate}

In an international perspective, the work of the MacBride Commission clearly made a valuable contribution. Sixteen representatives from different parts of the world agreed on an uncommonly concrete document that included a draft program of measures. Although its contents were partly controversial, the report definitely influenced UNESCO's subsequent communication policies. The work of the Commission ordered the issues in a structure that made it possible to raise the level of the debate. The solutions offered lent the issues concretion. We find support for this in the many references to the MacBride Commission in the debates in the Programme Commission and in the resolutions adopted in connection with the communication program. Moreover, many different media figured in the discussions of the 1980s, whereas news services and the press had dominated earlier. Finally, the MacBride Commission's emphasis on conditions in the third world also contributed to the change of course.

\section{The creation of the IPDC}

The creation of the IPDC came to symbolize the new direction of UNESCO communication policy, with its stress on development and practical measures. Development assistance was once again in center stage. The Western countries expressed warm enthusiasm for the IPDC and considered themselves the 'authors' of the project. Had the MacBride Commission not focused on development aspects, the program would most probably not have been instituted. The IPDC 
was the focus of discussion in all the sessions of the Programme Commissions through the 1980s. The existence of the IPDC also affected the meaning of certain central concepts, in that they came increasingly to be discussed in direct relation to the program. As the IPDC assumed a central role in UNESCO communication policy, issues relating to development assistance also came to the fore, at the expense of international perspectives.

\section{UNESCO and its Director-General under fire}

Under the leadership of Director-General Ahmadou-Mahtar M'Bow, UNESCO was criticized for having politicized information issues, for inefficiency and an exceedingly large (and growing) bureaucracy. Particularly the Director-General was accused of favoring the developing countries, and particularly African countries. The sharpest criticism was delivered by the USA and a number of European countries, Great Britain principal among them. Issues relating to the media and mass communication had more or less brought UNESCO to a standstill; in order for the organization to be able to fulfill its mandate, some change was absolutely necessary. The pressure of criticism forced Director-General M'Bow to modify his stance. Among other things, he declined to bring the MacBride Commission's 82 recommendations up for debate at the 1980 General Conference, assuming instead the role of mediator between the opposing blocs.

\section{Exit the USA and Great Britain}

Obviously, the American and British threats to leave the organization and their subsequent departure had an impact on UNESCO. Even before they withdrew, the intensity of the confrontations within UNESCO abated, and the General Conferences of 1983 and 1985 were relatively quiet and characterized by an uncommon willingness to meet the amendments proposed by the USA and Great Britain half way. In this respect, the exits of the two powers brought about a change in power relationships within the organization. The influence of the Director-General shrank, as criticism of his role intensified. The Western countries consolidated their strength, while the influence of the nonaligned bloc declined, and the Eastern bloc remained relatively passive. As a result, in 1985 the seemingly eternal bone of contention, the issue of the social responsibility of mass media, could be stricken from UNESCO's agenda, after nearly fifteen years' strife. The exit of the two major members also represented a loss of more than 30 per cent of UNESCO's revenues - which in itself weakened the organization.

Thus, it was the confluence of several factors that brought about the change of course in UNESCO during the 1980s. One should not, however, ignore more general changes in international politics of the era, factors like the 'détente' and the talks on disarmament that came with the thaw in the Cold War. These naturally affected the context in which UNESCO operated. But new power relationships were soon established as a result of political conflicts and changed market conditions. Tensions between the USA and the Soviet Union rose again to a new crescendo with the Soviet invasion of Afghanistan in 1979, which had a palpable impact on the climate in the Untied Nations and its specialized agencies in the early 1980s. Another more general feature of the times is the weakened position of the non-aligned movement in the 1980s, a development that has to do with OPEC's declining importance in the oil market. Open hostilities, even hot wars, had broken out between several of OPEC's members, which made it increasingly difficult for the oil-exporting countries to present a united front to the outside world, as they had in the 1970s (cf. Bartelson \& Ringmar 1985, Karlsson 1993, MacBride \& Roach 1993).

In sum we may see the issue of a new world communication order as an expression of the spirit of the times, an era of ideological debate and conflict, a period in which power relationships on international markets were challenged and changed. The issue of a NWICO, as formulated in the 1970s within UNESCO, was an outgrowth of the development paradigm and its ideological components. This, and the venue, the international arena UNESCO represented, made it possible to challenge the prevailing order and urge reform. In a longer perspective we also see that the 1970 s formed a period of transition, from politics and ideology to market solutions. The 1950 s and 1960 s were, overall, optimistic. Rich countries prospered, poor countries gained their independence. People had faith in political solutions, believed in the promise of new technology and economic growth. But in the 1970s this faith weakened; ideological conflicts surfaced, the status quo was questioned, and collective solutions were advanced. The 1980 s, then, saw the disintegration of many of the very institutions that had inspired optimism twenty and thirty years earlier. Deregulation, commercialization, consumerism and individualism became watchwords. The change 
was clearly linked to the advance of technologydriven globalization.

Looking back, we see that signs of a new economic world order could be discerned as early as the 1970 s. Later, in the 1980 s, a new political world order did in fact emerge. The driving forces behind this latter metamorphosis were quite beyond reach of the international political system; they were also, ideologically speaking, quite contrary to the thinking behind NWICO.

\section{The Information and Communication Order in the Era of Globalization}

\section{Globalization of the Media}

The face of world politics changed drastically in the first years of the 1990s with the disintegration of the Soviet Union and the fall of communist governments in Eastern Europe. A far-reaching restructuring of markets worldwide ensued, and the past decade has witnessed the successive commercialization, deregulation and privatization of many sectors. Globalization, particularly of markets, has permeated the public sphere and many aspects of our daily lives. National markets are becoming integrated into a global market structure. National frontiers are fading in many other respects, as well. Not least in the media system, where technological innovation and deregulation, particularly in the field of telecommunications, have accelerated the process. A new political and economic world order has brought changes in the information and communication order, too.

The contrasts between North and South have changed little since the 1970 s, when the issue of a NWICO was raised. This is made abundantly clear in Human Development Report, published annually by the UN Development Programme, UNDP. On the whole, underdevelopment and poverty have declined since the 1950s. Freedom from colonial rule brought improvements with regard to education and health care and a more rapid pace of economic growth. But the development process has proven a rocky road. To mention but one example: globalization creates tensions that have increased or threaten to increase poverty. Every fourth person in the world today subsists on an income of less than one U.S. dollar a day. UNDP not only forecasts a low rate of economic growth and stagnation for the developing countries, but goes on to identify a number of stumbling blocks to development such as political conflicts and war, slower progress in fields like food security, and the spread of HIV/AIDS (Human Development Report 1997-2002).
Properly structured, globalization can lead to a more just, peaceful and secure world. Globalization holds the promise of reducing inequalities and poverty through trade, technology diffusion and the exchange of knowledge, and through greater consciousness of shared values such as democratic rule and human rights.

The globalization we see today, however, is not always global. In some respects the world is more fragmented today than perhaps ever before; there are sharp divisions - between rich and poor, between the powerful and the powerless. Thousands of millions of people lack access to the mutual interaction that globalization makes possible. Exclusion is the plight of the poorest countries of the south, yes, but also of the poorest in the richest countries. Virtually every country of the world knows the problems and conflicts this gives rise to: widening income gaps, poverty, environmental degradation, ill health, ethnic conflict, racism, inequality of men and women, discrimination, intolerance, etc.

Exclusion is more than a question of material assets - it is also a question of access to knowledge and culture, i.e., the fundaments of social development. Unless the cultural diversity inherent in society is acknowledged and represented in the public sphere, no positive political, economic or social development will be possible.

For many people, globalization has meant that the world is shrinking. We have gained access to cultures and knowledge that were previously beyond our ken. Cultural frontiers are being transcended and a great diversity of actors are active on the global stage. But there is a down side, as well; globalization may also lead to homogenization, to the extinction of uniqueness, of definitive cultural idiosyncrasies. The institutions and companies that control globalized culture today tend toward standardization; commercial interests steer, and there is a risk that the interests of the wealthier peoples of the world, consumers, will prevail. At the same time, the world seems in some respects to be becoming less accessible. Everywhere in the world there are people who feel a need to defend their cultural identities. As a consequence, the frontiers between nations, cultures and religions are being turned into 'front lines', locally and internationally. Transcendence and lines of defense are two simultaneous phenomena in the same globalization process.

Mass media play a decisive part in what we call the globalization process. Without the media and modern information technology globalization as we know it today would not be possible. Access to 
various media, to telephony and digital services are often held forth as crucial to our political, economic and cultural development. Free and independent media are also vital to the survival and development of democracy. Meanwhile, a good share of the people of the world lack electricity and access to telecommunications and are thereby condemned to marginalization.

The development of innovative information technologies and the ongoing processes of deregulation and concentration of ownership have spurred the pace of globalization. Particularly communications satellites and digitalization - not least the Internet - have had an enormous impact. These innovations have opened worldwide markets for media products such as television programs, films, news, games and advertising. They have been a sine qua non for the formation and proper functioning of global enterprises and flows of information across national frontiers. The production and distribution of media products are highly concentrated branches, with respect to both content and ownership. Meanwhile, traditional distinctions, between information and entertainment, between hardware and software, between product and distribution, are blurring.

Much of what could be only vaguely discerned on the horizon back in the 1970s is now upon us in full force. The volume of information we have at our disposal has multiplied many times over; it is available via many new players via many new channels in 'the new information society'. The relationships between the rich countries and the poor countries of the world that the MacBride Commission described at the end of the 1970 s seem to prevail, essentially unchanged. Issues relating to mass media have been marginalized within UNESCO, and the world today is far too fragmented for an issue like 'the right to communicate' to gain acceptance. In sum, there is no basis in reality for a political discussion of how to regulate the international media system, as was done in the 1970s.

\section{Global Actors in the Media Market}

\section{News Flows - the Same Principal Actors Then as Now}

Much of the debate about a NWICO in the 1970s revolved around news flows across national frontiers. Studies made in the 1970 s confirmed a decided imbalance in the flows between North and South. One of the main demands regarding a NWICO was the call for a more equitable and democratic flow of information; initially, mainly flows of news.
The objects of the non-aligned countries' criticism were mainly the major wire services that operated worldwide: AP, AFP, dpa, Reuters and UPI. Because of their dominance they were held responsible for the 'one-way flow' of news and other information between North and South.

The international wire services were pioneers in the development of a global network. Having started up in the early 1850 s, they were the first transnational media systems, products of modernity. They defined political and economic news, thereby creating a product that was sold, in different packaging, to political and economic elites, either directly or via mass media, at home and in other parts of the world. The wire services developed information technologies so as to improve the global communications networks. Today, they distinguish themselves from other acctors on the global market in that they both contribute to globalization and consolidate their own countries. (Hjarvard 2001)

Contemporary news flows differ from those of the 1970s through a much larger volume and through greater diversification. But interest in using other sources than the major wire services is limited so that they have retained their privilege of defining what constitutes news. They, particularly market leaders AP and Reuters, also supply Internet services with news copy. Here there is a natural link to the main sources of news film. The news market today is highly diversified and segmented into a number of subgenres: business news, sports news, entertainment news, medical news, and the Internet facilitates further development, both in terms of geographical extent and volume. But the content the services carry does not seem to have evolved to any notable extent. When CNN 'stole' a sizable share of the global market in the mid-1990s, the dominance of the USA in news reporting worldwide was the target of criticism, and researchers found that 'the news seen on World Report is the same old news of the world' (Fluornoy \& Stewart 1997:23).

Some collaboration between established news agencies (EBU) and news agencies in the third world was established in the 1980 s as a direct consequence of the NWICO debate. Danish media scholar Stig Hjarvard, who has studied the exchange of news footage within Eurovision, found that Asia (Asiavision) is the only region where the EBU regularly gathered news in the 1990s. Otherwise, use of third world sources is no more than sporadic. Less than four per cent of the material carried by EBU's news exchange, EVN, in 1991 originated in regional collaboration with third world news organizations. 
To some extent, the sparse representation may be attributed to a scarcity of material that is of relevance to EBU's viewers. Hjarvard analyzed the obstacles and disinterest that collaboration has met on the national level and comments that collaboration seems to occur despite, rather than as a result of, national policy. Interest resides among journalists, not governments (Hjarvard 1995:505).

But even if regional collaboration has not brought about any major changes, regionalization of news reporting has developed, particularly in the Arab world. The news service, Al jazeera is a case in point. But this is not to say that $\mathrm{Al}$ jazeera is a major news source outside the Arab world.

An examination of the structure of the production and distribution of media products does not turn up any thoroughgoing changes since the 1970s as far as news flows are concerned. Researcher Oliver Boyd-Barrett presumes that nothing has changed and points out that the most problematic aspect today resides not so much in the skew geopolitical pattern of news diffusion as in the effects of the very narrow range of news content carried, the focus on elites and conventional Western news values, viz., conflict rather than stability, events rather than processes (Boyd-Barrett 1997). This, despite the fact that, thanks to the Internet, many more different news sources around the world are available than was even conceivable 20-30 years ago. That is to say, there is an unprecedented potential for both more diverse and more extensive news flows.

\section{Transnational Media Companies Grow Even Bigger}

Critics of the status quo in the 1970s took the concentration in the media branch and the threat to diversity that it posed as cause to demand some form of international regulation of media markets. Since then, media corporations have grown considerably.
Back in the 1970s, the objects of concern were the major wire services and, above all, film studios that operated on the international market, e.g. Columbia, Warner Brothers, Twentieth Century-Fox, United Artists - all based in the USA. Indeed, it is among these companies that we find the germ of many of the transnational corporations (TNC) that dominate the media market today. Some of these companies have taken advantage of deregulation and privatization in vast regions of the world and purchased and fused with other companies to become global media conglomerates.

The TNCs operate on multiple levels, global channels spread the same message (in the same language), regional channels in local languages are established, and technical systems are made available. A few transnational media companies, most of which are based in the USA or Europe, dominate the spread of media products. Their cultural presence is considerable on virtually every continent. Lately, they have begun to establish themselves in the developing countries. Together with the World Wide Web, the expansion of media TNCs also has increased the paramountcy of English.

Most of these companies are primarily involved in television and entertainment, but several also deal in news gathering and distribution. All control more than one medium and are thus able to advertise and sell their products in one medium via one or more others.

Both of the two transnational corporations in the third world are to be found in Latin America. They are Globo in Brazil and Televisa in Mexico. Globo is the larger with a volume of roughly USD 3 billion (Variety Aug 26-Sep 1, 2002). Having started out in the newspaper branch, the company now has expanded into television, pay-TV, music publishing and book publishing.

The media have become increasingly commercialized over the past few decades. Market shares are

\section{Table 1. The Largest Media Corporations in the World, by Media Sales Volume 2001 (USD billions)}

$\begin{array}{cl}\text { 1. } & \text { AOL Time Warner } \\ \text { 2. } & \text { Viacom (Inc.) } \\ \text { 3. } & \text { Vivendi Universal } \\ \text { 4. } & \text { The Walt Disney Company } \\ \text { 5. } & \text { Bertelsmann AG } \\ \text { 6. } & \text { News Corporation } \\ \text { 7. } & \text { Sony Corporation } \\ \text { 8. } & \text { Reed Elsevier } \\ \text { 9. } & \text { Gannett Co., Inc. } \\ \text { 10. } & \text { Pearson PLC }\end{array}$

Source: Nordicom 2003

USA
USA
France/USA
USA
Germany
Australia
Japan
The Netherlands
USA
Great Britain

Great Britain 
worth a great deal of money. How economic transactions are organized and the degree of concentration of economic power in various branches play a decisive role in the globalization process. A country's place in the global pecking order is a function of its ability to compete on the world market. Competitive strength is not only a question of efficiency or economic rationality; many factors - political, social and economic - play in. Samir Amin points out five different monopolies that the dominant actors make use of to maintain and strengthen their hold on the market and that together form the framework in which globalization takes place. The five monopolies relate to technology, finance, natural resources, media and communications, and weapons of mass destruction. In the case of the media and communications, Amin gives the following motives:

\begin{abstract}
[The media and communications] not only lead to uniformity of culture but also open up new means of political manipulation. The expansion of the modern media market is already one of the major components in the erosion of democratic practices in the West itself. (Amin 1997:5)
\end{abstract}

\section{The Media Situation in the Third World: Status Quo?}

The issues of cultural identity and the right to participate in international flows of information is related to both national media structures in the developing countries and the countries' links to the global system. The only concrete political result of the work on a NWICO within UNESCO was a focus on development of national media in the third world through, among other things, increased development assistance.

Several countries in the third world still lack adequate infrastructure for modern mass media. This hinders the countries' development, while it also blocks their access to the international news and media system. The lack of electricity and telecommunications in much of developing countries' territory is one key problem. Other hindrances reside in the realm of national media policy. Those who can change the situation are not always motivated to do so; those who want to change the situation are not always in a position to.

An examination of existing international statistics in the communications sector shows some improvement in the countries of the third world since the 1970 s, in some countries more than others. For example, the density of radio and television receivers has risen, as has newspaper circulation. Particularly the broadcast media have expanded. In the mid-1960s UNESCO recommended that each country should have at least $20 \mathrm{TV}$ sets, 50 radio receivers and 100 newspaper copies per thousand inhabitants. In 1980, the MacBride report notes that 100 countries of Africa, Asia and Latin America had not reached these minimum standards by the mid1970 s. Ten years later, five countries were still below the three standards, and an additional 55 were below at least one of them. African countries predominated among these least developed countries with respect to the media (Beam 1992). Ten years further down the line, the figures have further im-

Table 2. Media Densities in the World 1970 and 1997. Units per Thousand Inhabitants

\begin{tabular}{|c|c|c|c|c|c|c|}
\hline & \multicolumn{2}{|c|}{ Daily newspapers } & \multicolumn{2}{|c|}{ Radio receivers } & \multicolumn{2}{|c|}{ TV sets } \\
\hline & 1970 & 1996 & 1970 & 1997 & 1970 & 1997 \\
\hline The world, total & 107 & 96 & 245 & 418 & 81 & 240 \\
\hline Africa & 12 & 16 & 93 & 216 & 4.6 & 60 \\
\hline America & 170 & 141 & 698 & 1017 & 209 & 429 \\
\hline Asia & 49 & 66 & 81 & 255 & 20 & 190 \\
\hline Europe & 281 & 261 & 465 & 729 & 205 & 446 \\
\hline Oceania & 269 & 227 & 779 & 1071 & 188 & 427 \\
\hline Developing countries & 29 & 60 & 90 & 245 & 9.9 & 157 \\
\hline Sub-Saharan Africa & 10 & 12 & 83 & 202 & 1.5 & 48 \\
\hline Arab states & 17 & 36 & 131 & 269 & 21 & 119 \\
\hline Latin America \& Caribbean & 76 & 101 & 196 & 412 & 57 & 205 \\
\hline Eastern Asia \& Oceania & 26 & 56 & 97 & 306 & 3.3 & 253 \\
\hline Southern Asia & 12 & 33 & 34 & 118 & 0.9 & 54 \\
\hline Least developed countries & 4.5 & 8 & 56 & 142 & 0.5 & 23 \\
\hline Developed countries & 292 & 226 & 643 & 1061 & 263 & 548 \\
\hline
\end{tabular}


proved - in some countries, but not others. Again, the poorest countries of Africa lag behind. In several developing countries, the pace of progress in the media sector has been quite slow, particularly in rural areas, where a majority of the people live.

In the world as a whole, it is estimated that there is about 250 television sets per thousand inhabitants, a considerably greater share than have a telephone (Human Development Report 2002). In less than a decade, from the mid-1980s to the mid 1990 s - the number of television channels in the world doubled, as did average viewing time and the number of TV sets in households. Satellite television is accessible worldwide; transnational satellite channels have vastly increased the volume of programming available, and numerous niche channels carry specialized content to various target audiences - not least young viewers. In developing countries, which have experienced rapid deregulation, many Westernstyle radio and television channels now serve urban areas. Feature films, serial drama, talk shows and music predominate. Still, not everyone has access to television. In the poorest countries the estimated density of television sets per thousand people is no more than 23 (UNESCO 2003).

Radio is still the medium that reaches the most people. The fact that a good share of the third world still lacks electricity makes radio crucially important outside urban areas. Between 1970 and 1997 , the density of radio receivers in developing countries increased from 90 to 245 per thousand inhabitants (Table 2).

In the interval 1970-1997, newspaper circulation in the developing countries doubled, from 29 to 60 per thousand. Circulation nearly doubled in the least developed countries, as well: from 4.5 per thousand in 1970 to 8 per thousand in 1997. Still far below the UNESCO recommendations of the mid-1960s (100 per 1000 inhabitants).

The Internet is generally considered the cardinal example of "the digital revolution". In 2002, an estimated ten per cent of the world population had access to the Internet. More than three-quarters of today's Internet users are to be found in the wealthiest (OECD) countries, which have 14 per cent of the world population. Only one per cent are located in Africa. (Carlsson 2002). Thus, we find a huge gap between different parts of the world - 'the digital divide' is as wide today as it ever was. Most prognosticators say that the new information technology will make a tremendous difference in the future, but that a majority of the people of the world will not have access to the Net. The lack of telecommunications in- frastructure in regions of Africa, Asia and Latin America will keep many people in the margins.

Internet is known to be the younger generation's medium par excellence. But in Africa, South America and a good part of Asia, the share of children and young people who have Internet access is only a couple of per cent. Meanwhile, roughly 80 per cent of Swedish children have Internet access at home. Children and young people in the wealthiest countries of the world are a truly multimedia generation, whereas many of the children in the world cannot watch television, and books are in short supply.

The IPDC was inaugurated to accelerate the expansion of mass media in the third world. But, after twenty years, the results of the program are modest, to say the least. In some instances support made possible through the IPDC has significantly contributed to regional news exchanges, and to some extent the IPDC may be credited with having facilitated news gathering. But all too often, national media policy has stood in the way of international news exchange and news gathering across national frontiers.

IPDC operations have been criticized widely, and in 1995 reforms designed to make the program more efficient got under way. But at the same time it is difficult to see how the IPDC can help to create functional media structures. The establishment of modern communications infrastructure is much too costly for any one development program. Deregulation in the third world has opened the door to competition, privatization and foreign ownership, but this route to development often implies new dependency relationships.

The conditions found in the third world in the 1970 s are largely unchanged in the 100-odd countries that have experienced a slow pace of development and are still politically and economically dependent on other countries. In these countries, the situation described in the MacBride Commission's report still applies.

\section{A Third Development Paradigm}

The new world information order, as formulated by the non-aligned countries, was clearly linked to the dependence paradigm, particularly the elements, decolonization and demonopolization. But the documents also contained an indication of a new position in the countries' quest for their own paths toward development and communication; it had to do with independence, self-determination and cul- 
tural identity. The demand for a new international information order may be seen as a reaction to the modernization paradigm.

The MacBride Commission was clearly influenced by the non-aligned states' ideas. Self-reliance and cultural identity were key principles in the Commission's recommendations. Concepts like access and participation were made explicit. The Commission also introduced the local level and horizontal communication into thinking about development. There was also a hint of the idea that the causes of underdevelopment might be found in the developed and the developing countries alike. This 'new' view was also expressed in the IPDC resolution of 1980.

The MacBride Commission's recommendations were hardly unequivocal, however. The ambiguities were particularly apparent in the Commission's treatment of communication technology and technological development. Here the Commission's thinking alternated between the modernization and dependency paradigms; the concept of neocolonialism confronted decolonialization. But, above all, the recommendations suggested a third, alternative concept of development.

In the early 1980 s, some scholars and development experts began speaking of 'another development', a term first coined in 1978 in Development Dialogue, the journal published by the Dag Hammarskjöld Foundation. Here, key concepts are cultural identity and self-reliance and access and participation. This third approach may be characterized as a reaction to both the modernization and dependency paradigms. Universal models, which of necessity are always simplistic, are rejected in favor of an emphasis on the characteristics and needs of each individual country and the conviction that development efforts must start with specific conditions and needs. Social, economic, cultural and religious components of development are identified; and the focus rests more often on local conditions than on the nation or international relations. This is not to say that relationships of international interdependency were ignored. An oft-cited phrase was, "Global problems, local solutions". Adherents of this approach also regarded traditional values as an important factor for fostering a sense of identity and meaning and a source of continuity in the face of social change. At the same time, democratic processes and regard for human rights were kept in focus. (Hedebro 1982, Kothari 1984, Jayaweera 1987, Kumar 1994, Mowlana 1988, Servaes 1989, Yoon 1996)
In most recent decades, much of the work on 'another development' has focused on the concept of multiplicity, a concept introduced by Jan Servaes in the late 1980s. The principal features of 'the multiplicity model' may be summarized in five points:

1. All nations are interdependent in one sense or another. Internal as well as external factors can therefore influence the development process.

2. Development should be considered in a global context, in which both Center and Periphery, as well as their interrelated subdivisions, are taken into account.

3. There is no generally applicable model of development; each country must devise its own development strategy.

4. Development comes of self-reliance and cultural identity.

5. Development requires access to and participation in local communication systems, that is to say, horizontal communication (Servaes 1997, 1999, 2002).

This third development paradigm is characterized by pluralism. Thinking about participatory communication for social change has also been elaborated. The approach is decidedly normative. The researchers and field workers who subscribe to this school of thought often work on local projects to create the preconditions for new communicative situations, often on a 'grassroots' level. (See further, for example, the work of J Servaes, J D Bordenave, J E Fair, T L Jacobson, K J Kumar, R Lie, S A White.)

The links between this third paradigm of development and the NWICO debate and the ideas implicit in the MacBride resolution are obvious. Concepts like self-reliance and cultural identity took their place on the international agenda and thus won political acceptance on the conceptual level. The MacBride Commission involved social scientists - sociologists, political scientists, educationalists, media scholars, and so forth - and other experts from all parts of the world, which ensured the inclusion of many of the concepts that were to recur in both theory and practice in ensuing decades. It is difficult, however, to distinguish cause from effect. In all probability the present position is to be credited the mutual exchanges between regions, academic disciplines, experts, politicians, etc., that the discussion of a NWICO and, not least, the MacBride Commission broke ground for. 


\section{From a Vision for NWICO and International Regulation to an Era of Multilevel Governance and WSIS}

The 1970s were a period of widespread criticism of established political systems and quests for alternatives to them. After the optimistic faith in technology and political solutions that characterized the early postwar years the spirit of the 1970s provided an aperture for a questioning of the international character and roles of mass media. With questioning came demands on the part of thirdworld countries for stronger international regulation of the media system, demands formalized in the call for a new international information order. The issue of a New World Information and Communication Order that occupied the UNESCO agenda of the 1970 s is unique in that for once, international diplomacy and policy-makers acknowledged the international character of the media, their structures, world-views and markets.

Some of the developments of this past decade could be discerned on the horizon even at the time of the endeavour for a NWICO. Indeed, increasing concentration of media ownership, monopolization of markets, and a decline in diversity were among the complaints the third world countries and others raised. But, it was quite impossible to envisage the breadth and depth of what was to come in the closing decades of the century. The globalization in the media system spurred by deregulation and privatization, concentration, commercialization and, not least, new information technology, could not be foreseen in its manifold entirety. It was these developments that ultimately sealed the fate of NWICO as an issue.

The globalization of the media has accelerated and the digital divide has widened in recent years, and international information and media issues are once again in focus on the international agenda. The consequences of strong actors' operations on the global media market also occupy many media scholars today. Even if the points of departure and terms of reference used today are quite different from those of the 1970s, 'development' is still bound up with the modernist project of the Western world. Today, however, solutions to the problems and issues are not sought in top-down steering and regulations on an international scale. Contemporary society is far too complex for that, and discourages the thought of 'a new international order' of the sort envisaged in the 1970s. Now we see the era of multilevel governance of the media and communication system - the interplay between many different actors, public and private, on multiple levels, from the local to the global.

One of the main items on the agenda today is The World Summit on the Information Society, WSIS. Arranged by the International Telecommunication Union (ITU) in partnership with, among others, UNESCO, under the high patronage of the UN Secretary-General, the WSIS will be held in two sessions: December 2003 in Geneva and November 2005 in Tunis. The "anticipated" outcome of the Summit is "to develop and foster a clear statement of political will and a concrete plan of action for achieving the goals of the Information Society, while fully reflecting all the different interests at stake" (www.itu.int/ wsis/basic/about). One of the fundamental ideas behind the WSIS has been to create a more inclusive Information Society and to bridge the digital divide in a North-South perspective. Over the course of a series of Preparatory Committee meetings the agenda of the session in Geneva appears to have become oriented toward telecommunication and Internet-related issues in an increasingly technical perspective.

Many voices, not least within the civil society, have called for more attention to media, human rights and communication rights in the final document from the WSIS. That is to say, the Universal Declaration of Human Rights, not least its Article 19 which emphasizes freedom of expression, and the principles of the free flow of information, the free circulation of ideas, freedom of the press, participation in the communication process, the right to communicate, cultural diversity, and so forth are once again in focus. It will require hard work to ensure that the Information Society, or the Knowledge Society in UNESCO's usage, is equate with the attainment of basic economic, social and political rights for people around the world. The significance of the WSIS will depend on the extent to which national governments, the private sector, the civil society and other relevant stakeholders are brought into the continued work toward these goals.

The challenges facing those engaged in issues of development and mass communication are thus many and multifaceted. The politicians, practitioners and researchers in this sector must be mindful of the past and of the shadows it casts, yet take care not to mistake those shadows for the realities of the day. 


\section{Notes}

1. The findings of the study are reported in full in Ulla Carlsson: Frågan om en ny internationell informationsordning; en studie i internationell mediepolitik (The issue of a New World and Information Order; a study in media politics). Göteborg: Göteborg University, Dept. of Journalism and Mass Communication, 1998.

2. The documents analyzed cover the period 19731980. They are:

Action Programme for Economic Co-operation of the 4th Summit Conference of the Non-Aligned Countries. Alger, Algeria August 1973.

Report of the Non-Aligned Symposium on Information. Tunis, Tunisia 30 March 1976.

Declaration of the Ministerial Conference of NonAligned Countries on Decolonization of Information. New Delhi, India 13 July 1976.

Political Declaration of the 5th Summit Conference of Non-Aligned Countries. Colombo, Sri Lanka August 1976.

First Meeting of Co-ordination Committee of the Non-Aligned News Agencies POOL. Cairo, Egypt 10-12 January 1977.

First Meeting of the Intergovernmental Council for Co-ordination of Information and the Mass Media in Non-Aligned Countries. Tunis, Tunisia 28 February-1 March 1977.

First Conference of Broadcasting Organization of Non-Aligned Countries. Sarajevo, Yugoslavia 2730 October 1977.

Second Meeting of the Co-ordination Committee of the Press Agencies POOL of Non-Aligned Countries. Djakarta, Indonesia 3-5 April 1978.

Second Meeting of Intergovernmental Council for the Co-ordination of Information of the Movement of Non-Aligned Countries. Havana, Cuba 17-20 April 1978.

Ministerial Meeting of the Co-ordinating Bureau of Non-Aligned Countries. Havana, Cuba 15-20 May 1978.

Third Meeting of the Co-ordination Committee of the Press Agencies POOL of Non-Aligned Countries. Kinshasa, Zaire 7-9 March 1979.

Resolution on Co-operation and Activities of NonAligned Countries in Information of the Third Meeting of the Intergovernmental Council Coordination of Information Among Non-Aligned Countries. Lomé, Togo 26 April 1979.

Political Declaration of the 6th Summit Conference of Non-Aligned Countries. Havana, Cuba 9 September 1979.

Statute of the News Agencies POOL of Non-Aligned Countries. Belgrade, Yugoslavia 24 November 1979.

Resolution of the New International Information Order to the Fourth Meeting of Intergovernmental Council for Co-ordination of Information Among Non-Aligned Countries. Baghdad, Iraq.
3. The Commission

From the West: Elie Abel, USA, journalist and Professor of Communication at Stanford University; Hubert Beuve-Mery, France, journalist and founder of Le Monde; Michio Nagai, Japan, journalist, sociologist, former Minister of Education; Johannes Pieter Pronk, The Netherlands, economist, politician; Betty Zimmerman, Canada, Director, Radio Canada International.

From the East: Sergei Losev, USSR, Director, TASS; Bogdan Osolnik, Yugoslavia, journalist, politician; From the third world: Elebe Ma Ekonzo, Zaire, journalist, Director, Agence Zaire Presse; Mochtar Lubis, Indonesia, journalist, Chairman, Press Foundation of Asia; Gabriel Garcia Marques, Colombia, author and Nobel laureate; Mustapha Masmoudi, Tunisia, Permanent Delegate of Tunisia in UNESCO, former Minister of Information, President, Intergovernmental Coordination, Council for Information of the Non-Aligned Countries; Fred Isaac Akporuaro Omu, Nigeria, professor, University of Benin; Gamar El-Oteifi, Egypt, former Minister of Information, journalist and jurist; Juan Somavia, Chile, Director, Instituto Latinamericano de Estudios Transnacionales (Mexico); Boobli George Verghese, India, journalist.

4. This section is based on an analysis of Records of the General Conference 1980 (vols 1-3) and, more specifically, Resolutions 4/19, International Commission for the Study of Communication Problems, and 4/21, International Programme for the Development of Communication. The 'legislative history' of these documents has been studied, as well. The General Conferences take place in two arenas: the plenary sessions, (particularly the general debate) and program commissions. The general debate consists of addresses by the heads of the national delegations. Introductory remarks are offered by the Chairman of the Board of UNESCO and the Director-General, respectively. It is in the program commissions that the actual work of the Conferences takes place: programs are proposed, budgets are drafted, and draft resolutions are formulated. The work done in the commissions is submitted to the plenary, whose decisions take the form of resolutions, some of which guide the work of UNESCO, while others are international agreements on specific issues. The statements of the delegations are recorded in extenso and verbatim, whereas the proceedings of the commissions are minuted in summary.

5. This part of the article is based on an analysis of UNESCO Records of the General Conference for 1982, 1983, 1985, 1987 and 1989. The very extensive and complex material in these documents was treated using the same analytical scheme as was applied to the recommendations of the MacBride Commission and the two resolutions adopted at the 1980 General Conference (Chapter $6)$. The prime focus of the analysis rests on the 
minutes of the Programme Commissions and the texts of adopted resolutions. Addresses in the general debate were also studied for information on the political context and for factors that might have a bearing on the treatment of information and communication issues during the period. IPDC programs are described on the basis of an analysis of IPDC annual reports, which report current objectives, financing, the focus of current projects and the countries involved. Additional material has been culled from other international and regional meetings and the observations of scholars and politicians.

\section{References}

A Documentary History of a New World Information and Communication Order Seen as an Evolving and Continuous Process 1975-1986. Paris: UNESCO (Communication and Society 19).

Amin, S. (1997) Capitalism in the Age of Globalization. London: Zed.

Bakdikian, B.H. (1997) The Media Monopoly (5 th $^{\text {ed }}$ edion). Boston: Beacon Press.

Baran, P. (1957) The Political Economy of Growth. New York: Monthly Review Press.

Bartelson, J. \& Ringmar, E. (1985) Två fallstudier: USA lämnar ILO och UNESCO [Two case studies: The USA leaves the ILO and UNESCO], in Huldt, B. \& Falk, M. (eds.) FN vid 40 - Internationellt samarbete $i$ kris. Stockholm: Utrikespolitiska Institutet.

Beam, S. (1992) Surveying the Territory: Re-examining MacBride and Theories of Development. Gazette 50(1992)2-3, 109-146.

Beltrán, L.R. (1980) Farewell to Aristotle: Horizontal Communication. Communication (1980)5, 5-41.

Biernatzki, W. (ed.) (1992) The Internationalization of Communications Law. Communication Research Trends 12(1992)4, 1-27.

Bishop, R. (1975) How Reuters and AFP Coverage of Independent Africa Compares. Journalism Quarterly 52(1975).

Bjereld, U. (1989) Svensk Mellanösternpolitik. En studie av Sveriges agerande och ställningstaganden gentemot konflikterna i Mellanöstern 1947-1985 [A study of Swedish policy and postures vis-à-vis conflicts in the Middle East 1947-19985], Stockholm: Carlssons.

Blomström, M. \& Hettne, B. (1984) Development Theory in Transition. The Dependency Debate and Beyond. London: Zed.

Boafo, S.T.K. (1987) Democratizing Media Systems in African Societies: The Case of Ghana. Africa Media Review 2(1987)1.

Bordenave, J.D. (1977) Communication and Rural Development. Paris: UNESCO.

Boyd-Barrett, O. (1980) The International News Agencies. London: Sage.
Boyd-Barrett, O. (1997) Global News Wholesalers as Agents of Globalization, i Sreberny-Mohammadi, A. et al (eds.) Media in Global Context. A Reader. London: Arnold, 131-144.

Boyd-Barrett, O. (1997) International Communication and Globalization: Contradictions and Directions, in Mohammadi, A. (ed.): International Communication and Globalization. London: Sage, 11-26

Braman, S. \& Sreberny-Mohammadi, A. (eds.) (1996) Globalization, Communication and Transnational Civil Society. Cresskill: Hampton Press.

Breuning, Ch. (1987) Kommunikationspolitik der UNESCO. Dokumentation und Analyse der Jahre 1946 bis 1987. Konstanz: Universitätsforlag Konstanz GmbH.

Cardoso, F.H. (1979) Dependency and Development in Latin America. Berkeley: University of California Press.

Carlsson, U. (1981) Nyheterna och tredje världen. En översikt av det internationella nyhetsflödet. [News and the third world; a study of international news flows]. Lund: Studentlitteratur.

Carlsson, U. (1991) En ny internationell informationsordning? En studie av MacBride-kommissionens arbete [A new international information order? The work of the MacBride Commission]. Göteborg: Göteborgs universitet, Institutionen för journalistik och masskommunikation.

Carlsson, U. (1991) Det internationella nyhetsflödet. En ny internationell informations- och kommunikationsordning [International news flows; A NWICO]. Göteborg: JMG, Göteborgs universitet.

Carlsson, U. (1998) Frågan om en ny internationell informationsordning; en studie i internationell mediepolitik [The issue of a New World and Information Order; a study in media politics]. Göteborg: Göteborg University, Dept. of Journalism and Mass Communication, 1998.

Carlsson, U. (2002) Foreword in Feilitzen, C. \& Carlsson, U (eds) Children, Young People and Media Globalisation. Göteborg University:Nordicom

Curran, J. \& Gurevitch M. (eds.) (1991, 2000) Mass Media and Society. London: Arnold.

D'Arcy, J. (1969) Direct Broadcast Satellites and the Right to Communicate. EBU Review 118.

Developing World Communications (1987). London: Grosvenor Press International.

Development Dialogue (1978)2, (1981)2, (1984)1-2, (1985)1, (1989)1.

Dinh van, T. (1987) Communication and Diplomacy in a Changing World. Norwood: Ablex.

Documents of the Non-Aligned Movement on the New International Information and Communication Order 1986-1987 (1988). Prague: International Organization of Journalists.

Dos Santos, T. (1970) The Structure of Dependency. American Economy Review 60(1970)21.

Downing, J.; Mohammadi, A. \& Sreberny-Mohammadi, A. (1990) Questioning the Media - A Critical Introduction. London: Sage. 
Dyvi, E.B. \& Rønning, H. (1995) UNESCO's International Programme for the Development of Communication (IPDC). A Desk Study. Oslo: University of Oslo, Department of Media and Communication.

Easton, D. (1965) A Framework for Political Analysis. Englewood Cliffs: Prentice-Hall.

Eek, H. (1979) Principles Governing the Use of the Mass Media as Defined by the United Nations and UNESCO, in Nordenstreng, K. \& Schiller, H. (eds.) National Sovereignty and International Communication. Norwood: Ablex.

Eek, H.; Bring, O. \& Hjerner, L. (1987) Folkrätten. Staternas och de mellanstatliga organisationernas rättsordning [International law. The legal systems of nation-states and international organizations], Stockholm: Norstedts.

Ellingsen Tunold, B.M. (1984) The UNCLOS III Negotiations and the Deep Sea-bed Regime: The Common Heritage of Mankind for the Benefit of Mankind as a Whole. Oslo: Fridtjof Nansens Institut.

Fascell, D.B. (ed.) (1979) International News. Freedom Under Attack. Beverly Hills: Sage.

Featherstone, M.; Lash, S. \& Robertson, R. (eds.) (1995) Global Modernities. London: Sage.

Fischer, D. (1982) The Right to Communicate: A Status Report. Paris: UNESCO (Reports and Papers on Mass Communication 49).

Flournoy, S.M. \& Stewart, R.K. (1997) CNN Making News in the Global Market. Luton: John Libbey Media.

Frank, A. Gunder (1969) Capitalism and Underdevelopment in Latin America. New York: Monthly Review Press.

Galtung, J. (1971) A Structural Theory of Imperialism. Journal of Peace Research 8(1971)2, 81-118.

Galtung, J.; O’Brien, P. \& Preiswerk, R. (eds.) (1980) Self-Reliance: A Strategy for Development. London: Bogle-L'Ouverture.

Garbo, G. (1983) The Role of the IPDC in the Implementation of the New World Information and Communication Order. Presentation at Conference of NAMEDIA, New Delhi, India 9-12 December 1983.

Garbo, G. (1984) Over alle grense. Den internasjoncele informasjonsformidlingen, mediesamfunnet og utviklingslandene [Across all frontiers: International exchanges of information, the media society, and developing countries]. Oslo: Det Konglige Utrikesdepartement.

Gerbner, G. (1977) Mass Media Policies in Changing Cultures. New York: John Wiley.

Gerbner, G. (1993) UNESCO in the US Press, in Gerbner, G.; Mowlana, H. \& Nordenstreng, K. (eds.) The Global Media Debate: Its Rise, Fall, and Renewal. Norwood: Ablex.

Gerbner, G. \& Siefert, M. (eds.) (1984) World Communications. A Handbook. New York/London: Longman.
Gerbner, G.; Mowlana, H. \& Nordenstreng, K. (eds.) (1993) The Global Media Debate: It's Rise, Fall, and Renewal. Norwood:Ablex.

Giddens, A. (1984) The Constitution of Society: Outline of the theory of Structuration. Cambridge: Polity Press.

Giddens, A. (1990) The Consequences of Modernity. Stanford: Stanford University Press.

Giddens, A. (1991) Modernity and Self-Identity: Self and Society in Late Modern Age. Cambridge: Polity Press.

Giddens, A. (1996) Modernitetens följder [The consequences of modernity]. Lund: Studentlitteratur.

Giffard, A.C. (1989) UNESCO and the Media. New York: Longman.

Goddard-Power, S. (1981) The U.S. View of Belgrade. Journal of Communication 3(1981)4.

Goddard-Power, S. (1984) UNESCO at Belgrade: The U.S. View, in Gerbner, G. \& Siefert, M. (eds.) World Communications. New York/London: Longman.

Golding, P. \& Harris, P. (eds.) (1997) Beyond Cultural Imperialism. Globalization, Communication and the New International Order. London: Sage.

Gonzalez, J. (1997) The Willingness to Weave: Cultural Analysis, Cultural Fronts and Networks of the Future. Media Development (1997)1, 30-40.

Goodrich, L.M. (1974) The United Nations in a Changing World. New York: Columbia University Press.

Gross, L. (1979) Some International Law Aspects of the Freedom of Information and the Right to Communicate, in Nordenstreng, K. \& Schiller, H. (eds.) National Sovereignty and International Communication. Norwood: Ablex.

Hamelink, C. (1979) The New International Economic Order and the New International Information Order. Paris: UNESCO (International Commission for the Study of Communication Problems 34).

Hamelink, C. (1980) Communication in the Eighties: A Reader on the MacBride Report. Rome: IDOC.

Hamelink, C. (1989) UNESCO: the New International Information Order, i Everts, P. \& Walraven, G. (eds.) The Politics of Persuasion. Aldershot: Avebury.

Hamelink, C. (1997) MacBride with Hindsight, in Golding, P. \& Harris, P. (eds.) Beyond Cultural Imperialism. Globalization, Communication and the New International Order. London: Sage.

Hamelink, C. (1997) The Politics of World Communication. London: Sage.

Hamelink, C. \& Pavlic, B. (1985) The New International Economic Order: Links Between Economics and Communications. Paris: UNESCO (Reports and Papers on Mass Communication 98).

Harley, W.G. (1981) The U.S. State in IPDC. Journal of Communication 3(1981)4.

Harley, W.G. (1984) UNESCO and the International Programme for the Development of Communications, in Gerbner, G. \& Siefert, M. (eds.) World Communications. New York/London: Longman. 
Harris, P. (1976) International News Media Authority and Dependence. Instant Research on Peace and Violence (1976)4.

Harris, P. (1976) Selective Images: An Analysis of the West African Wire Service of an International News Agency. Paper prepared for the fourth session of the IAMCR 10th General Assembly and Scientific Conference, University of Leicester 30 August-4 September 1976.

Hedebro, G. (1982) Communication and Social Change in Developing Nations: A Critical View. Ames: Iowa State University Press.

Held, D. McGrew, Godblatt\&Perraton (1999): Global transformations: Politics, Economics and Culture. Cambridge: Polity Press

Herman, E.S. \& McChesney (1997) The Global Media. The New Missionaries of Corporate Capitalism. London: Cassel.

Hettne, B (1990) Development Theory and the Three Worlds. New York: Longman

Hjarvard, S. (1995) Internationale TV-nyheder. En historisk analyse af det europaiske system for udveksling af TV-nyheder [International TV news; An historical analysis of the European news exchange system]. Århus: Akademisk forlag.

Hjarvad, S. (ed) (2001) News in a Globalized Society. Göteborg: Nordicom, Göteborg University

Holsti, K.J. (1967) International Politics. A Framework for Analysis. Englewood Cliffs: Prentice Hall

Human Development Report 1997-2002. UNDP, New York: Oxford University Press

Höhne, H. (1977) Report über Nachrichtenagenturen. 1. Die Situation auf den Nachrichtenmärkten der Welt. Baden-Baden: Nomos Verlagsgesellschaft.

Innis, H. (1972) Empire and Communications. Toronto: University of Toronto Press.

Jacobson, T. (1994) Modernization and Post-Modernization Approaches to Participatory Communication for Development, in White, S. (ed.): Participatory Communication. Working for Change and Development. London: Sage, 60-75.

Jacobson. T. (1997) Conclusion: Prospects for the Theoretical Development, in Servaes, J. et al (eds.) Participatory Communication for Change. London: Sage, 266-277.

Jayaweera, N. \& Amunugama, S. (eds.) (1987) Rethinking Development Communication. Singapore: Asian Mass Communication Research and Information Centre.

Journal of Communication 31(1981)4, 32(1982)4, 34 (1984)4, 35(1985)4.

Karlsson, S. (1993) USA, oljan och världsordningen [The USA, oil and the world order]. Stockholm: Nerenius \& Santérus.

Katz, E. \& Szecskó, T. (eds.) (1981) Mass Media and Social Change. Beverly Hills: Sage.

Kothari, R. (1984) Communication for Alternative Development: Towards a Paradigm. Development Dialogue (1984).
Kumar, K. (1994) Communication Approaches to Participation and Development: Challenging the Assumptions and Perspectives, in White S. (ed.): Participatory Communication. Working for Change and Development. London: Sage, 76-94

Lerner, D. (1958) The Passing of Traditional Society. Glencoe: Free Press.

Lerner, D. \& Schramm, W. (eds.) (1967) Communication and Change in Developing Countries. Honolulu: East-West Center.

Levin, H.J. (1984) U.S. Communication Policies at Home and Abroad: Are they Consistent?, in Gerbner, G. \& Siefert, M. (eds.) World Communications. New York/London: Longman.

MacBride, S. (1979) Shaping a New World Information Order. Paris: UNESCO (International Commission for the Study of Communication Problems 33).

MacBride, S. \& Roach, C. (1993) The New International Information Order, in Gerbner, G.; Mowlana, H. \& Nordenstreng, K. (eds.) The Global Media Debate: Its Rise, Fall and Renewal. Norwood: Ablex.

Many Voices, One World: Communication and Society. Today and Tomorrow (1980). Paris: UNESCO/London: Kogan Page (final report of the International Commission for the Study of Communication Problems).

Martín-Barbero, J. (1993) Communication, Culture and Hegemony. From Media to Mediations. London: Sage.

Masmoudi, M. (1978) The New World Information Order. Paris: UNESCO (International Commission for the Study of Communication Problems 31).

Mattelart, A. (1996) La mondialisation de la communication. Paris: Presse Universitaires de France.

McClelland, D.C. (1961) The Achieving Society. Princeton: Van Nostrand.

McChesney, R.W. (1999) Rich Media, Poor Democracy: Communication Politics in Dubious Timees. Urbana: University of Illinois Press

McQuail, D. (1984) Masskommunikationsteori [Mass communication theory]. Stockholm: Liber.

McQuail, D. (1987) Mass Communication Theory. An Introduction. London: Sage.

Mehan, J.A. (1981) UNESCO and the U.S. Action and Reaction. Journal of Communication 31(1981)4.

Moemeka, A. (1988) Mass Media and Rational Domination: A Critical Review of a Dominant Paradigm. Africa Media Review 3(1988)1.

Mohammadi, A. (ed.) (1997) International Communication and Globalization. A Critical Introduction. London: Sage.

Monographs I, II, III (1978) Paris: UNESCO (International Commission for the Study of Communication Problems 13, 14, 15).

Mosco, V. \& Wasko, J. (eds.) (1984) The Critical Communications Review. Vol II Changing Patterns of Communications Control. Norwood: Ablex.

Mowlana, H. (1997) Global Information and World Communication. London: Sage. 
Mowlana, H. \& Wilson, L. (1988) Communication Technology and Development. Paris: UNESCO (Reports and Papers on Mass Communications 101).

Mowlana, H. \& Wilson, L. (1990) The Passing of Modernity: Communication and the Transformation of Society. White Plains: Longman.

New International Information and Communication Order. Sourcebook (1986). Prague: International Organization of Journalists.

Nordenstreng, K. (1984) The Mass Media Declaration of UNESCO. Norwood: Ablex.

Nordenstreng, K. (1984) Defining the New International Information Order, i Gerbner, G. \& Siefert, M. (eds.) World Communications. New York/London: Longman.

Nordenstreng, K. \& Schiller, H. (eds.) (1993) Beyond National Sovereignty: International Communication in the 1990s. Norwood: Ablex.

Nordenstreng, K. \& Varis, T. (1974) Television Traffic A One-Way Street. A Survey and Analysis of the International Flow of Television Programme Material. Paris: UNESCO (Reports and Papers on Mass Communication 70).

Nostbakken, D. \& Morrow, C. (1993) Cultural Expression in the Global Village. Penang: Southbound.

Orek, O. (1978) Development Journalism and Press Freedom. An African View Point. Gazette 24(1978)

Our Creative Diversity. Report of the World Commission on Culture and Development (1995). Paris: UNESCO.

Peters, B.G. and Pierre, J. (2001) "Multilevel Governance: A Faustian Bargain?" paper presented at a the Conference "Multilevel Governance: Interdisciplinary Perspectives", Political Economy Research Centre, University of Sheffield, UK, 29-23 June 2001

Petersson, H.F. (1964) Power and International Order. Lund: Gleerups.

Ploman, E. (1982) International Law Governing Communications and Information: A Collection of Basic Documents. Westport: Greenwood.

Reyes Matta, F. (1981) A Model for Democratic Communication. Development Dialogue (1981)2, 7991.

Richstad, J. \& Anderson, M.H. (eds.) (1981) Crisis in International News: Policies and Prospects. New York: Columbia University Press.

Roach, C. (1993) American Textbooks vs NWICO History, in Global Media Debate:Its Rise, Fall, and Renewal. Norwood: Ablex.

Robertson, R. (1992) Globalization. Social Theory and Global Culture. London: Sage.

Rogers, E.M. (1962) Diffusion of Innovations. New York: Free Press.

Rogers, E.M. (ed.) (1976) Communication and Development. Critical Perspectives. Beverly Hills: Sage.

Rogers, E.M. \& Shoemaker, F. (1971) Communication of Innovation. A Cross-Cultural Approach. New York: Free Press.
Rosenau, J.N. (ed.) (1969) International Politics and Foreign Policy. New York: Free Press.

Said, E.W (1994) Culture and Imperialism. London: Vintage.

Schiller, H. (1976) Communication and Cultural Domination. White Plains: International Arts and Science Press.

Schramm, W. (1964) Mass Media and National Development. The Role of Information in the Developing Countries. Stanford: Stanford University Press.

Schramm, W. \& Lerner, D. (eds.) (1976) Communication and Change: The Last Ten Years - And the Next. Honolulu: University Press of Hawaii.

Schramm, W. (1979) Mass Media and National Development - 1979. Paris: UNESCO (International Commission for the Study of Communication Problems 42).

Schudson, M. (1991) Historical Approaches to Communication Studies, in Jensen K.B. \& Jankowski, N.W. (eds.): A Handbook of Qualitative Methodologies for Mass Communication Research. London: Routledge.

Seliger, M. (1976) Ideology and Politics. London: Allen \& Unwin.

Servaes, J. (1989) One World, Multiple Cultures. A New Paradigm on Communication for Development. Leuven: Acco.

Servaes, J. (2002) Communication for Development. One World, Multiple Cultures. Cresskill, New Jersey: Hampton Press.

Servaes, J. \& Lie, R. (eds.) (1997) Media and Politics in Transition. Cultural Identity in the Age of Globalization. Leuven: Acco.

Servaes, J.; Jacobson, T.L. \& White, S.A. (eds.) (1997) Participatory Communication for Social Change. London: Sage.

Singh, K. \& Gross, B. (1981) MacBride: The Report and the Response. Journal of Communication 31(1981)4

Somavía, J. (1981) The Democratization of Communications: From Minority Social Monopoly to Majority Social Representation. Development Dialogue (1981)2.

Sparks, C. \& Roach, C. (1990) Farewell to NWICO? Media, Culture and Society 12(1990)3, 275-281.

Splichal, S. (1990) NWICO - Dead or Alive? MacBride Round Table on Communication in Harare, 27-29 October 1989. Media, Culture and Society 12(1990)3.

Sreberny-Mohammadi, A.; Nordenstreng, K.; Stevenson, R.L. \& Ugboajah, F. (1984) Foreign News in the Media: International Reporting in Twenty-nine Countries. Paris: UNESCO (Reports and Papers on Mass Communication 93).

Sreberny-Mohammadi, A.; Winseck, D.; McKenna, J. \& Boyd-Barrett, O. (eds.) (1997) Media in Global Context. A Reader. London: Arnold.

Szecskó, T. \& Katz, E. (1981) Mass Media and Social Change. London: Sage. 
Tankha, B. (ed.) (1995) Communications and Democracy. Ensuring Plurality. Penang: Southbound.

Tehranian, M. (1985) Paradigms Lost: Development as Communication and Learning. Media Development 32(1985)4, 5-8.

Tehranian, M. (1994) Is There a New World Order? Journal of International Communication (1994)2, 71-99.

The Flow of News (1953). Zürich: IPI.

The Right to Communicate (1979). Paris: UNESCO (International Commission for the Study of Communication Problems 36, 37, 38).

Thompson, J.B. (1995) The Media and Modernity. A Social Theory of the Media. Cambridge: Polity Press.

Tomaselli, K. (1996) The Need for Global Solidarity. Media Development (1996)3, 27-31.

Tomlinson. J. (1991) Cultural Imperialism. London: Pinter Publishers.

Touraine, A. (1992) Critique de la modernité. Paris: Fayard.

Traber, M. \& Nordenstreng, K. (eds.) (1992) Few Voices, Many Worlds: Towards a Media Reform Movement. London: World Association for Christian Communication.

Tunstall, J. (1977) The Media are American. AngloAmerican Media in the World. London: Constable.
UNESCO Statistical Yearbook. www.unesco.org/uis (2003-03-03)

Wallerstein, I. (1984) The Politics of the World-Economy: The States the Movements and the Civilizations. New York: Cambridge University Press.

Varis, T. \& Jokelin, R. (1976) Television News in Europe. A Survey of the News-Film Flow in Europe. Tampere: University of Tampere, Institute of Journalism and Mass Communication.

Wasko, J. \& Splichal, S. (eds.) (1992) Communication \& Democracy. Norwood: Ablex.

Vedung, E. (1977) Det rationella politiska samtalet. Hur politiska budskap tolkas, ordnas och prövas [The interpretation, ordering and testing of political messages]. Stockholm: Aldus.

White, S. (ed.) (1994) Participatory Communication. Working for Change and Development. London: Sage.

Worsley, P. (1984) The Three Worlds: Culture and World Development. Chicago: The University of Chicago Press.

Yoon, C.S. (1996) Participatory Communication for Development, in Bessette G. \& Rajasunderam C.V. (eds.) Participatory Development Communication. A West African Agenda. Penang: Southbound. 